\title{
Coletivos e o uso das redes: o caso das ocupações das escolas de São Paulo em 2015
}

\author{
Collectives and the use of networks: the case of São Paulo \\ schools' occupancies in 2015
}

Colectivos y el uso de las redes: el caso de las ocupaciones de las escuelas de São Paulo en 2015

Recebido em 31-08-2020

Modificado em 03-10-2020

Aceito para publicação em 26-10-2020

https://doi.org/10.47456/simbitica.v7i3.33697

\section{Lucca Amaral Tori \\ ORCID: 0000-0003-0371-1003}

Mestrando pelo Programa "Humanidades, Direitos e Outras Legitimidades" na Faculdade de Filosofia, Letras e Ciências Humanas da Universidade de São Paulo (Brasil). E-mail: lucca.tori@usp.br

\section{Luana Hanaê Gabriel Homma}

ORCID: 0000-0003-1533-2406

Doutoranda e Mestre pelo Programa de Pós-Graduação em Ciências Humanas e Sociais da Universidade Federal do ABC (Brasil). E-mail: luana.homma@ufabc.edu.br

\section{Giuliana Fiacadori}

ORCID: 0000-0002-4688-701X

Mestre pelo Programa de Pós-Graduação em Ciências Humanas e Sociais da Universidade Federal do ABC (Brasil). E-mail: giuliana.fiacadori@ufabc.edu.br

\section{Resumo}

Este artigo aborda o uso das redes sociais, bastante relevantes para divulgação de informações e organização dos estudantes, durante o período de ocupações de escolas em 2015, a partir do estudo comparativo das duas páginas de Facebook mais atuantes durante os eventos: "O Mal Educado" e "Não Fechem Minha Escola". A primeira administrada pelo coletivo de mesmo nome e a segunda criada por ativistas não organizados. A metodologia utilizada incluiu entrevistas com administradores e análise de conteúdo de 50 publicações com maior engajamento de cada página. As páginas diferem em relação à visão sobre estratégia de comunicação, composição da administração e quanto às redes às quais pertenceram no movimento. As postagens analisadas se assemelham em temas abordados, mas apresentam algumas diferenças em relação aos enquadramentos e recursos utilizados.

Palavras-chave: coletivos; ocupações secundaristas; mobilizações em rede; Facebook. 


\section{Introdução}

No ano de 2013, houve uma movimentação massiva por todo Brasil, com movimentos que se assemelham aos protestos ocorridos desde $2011 \mathrm{em}$ diferentes partes do mundo (a chamada Primavera Árabe, o movimento dos Indignados na Espanha, o Occupy Wall Street nos EUA, entre outros). Pode-se observar semelhanças entre estes movimentos, como por exemplo: a predominância de jovens, a ausência de pauta específica, o não predomínio de organizações políticas tradicionais (como sindicatos e partidos políticos) e o uso intenso das tecnologias de informação e comunicação, principalmente das redes sociais. Esta última questão se mostrou essencial para a base e a explosão da participação nas chamadas Jornadas de Junho no Brasil.

Posterior a esse grande movimento no país, ocorreram tanto mudanças políticoinstitucionais quanto dos movimentos sociais em si: iniciaram-se os movimentos pelo impeachment da presidenta Dilma Rousseff, de apoiadores da presidenta (em oposição àqueles) e movimentos autônomos, como foi o caso das ocupações das escolas no estado de São Paulo em 2015, contrários à política de reorganização escolar do Governo Estadual.

O projeto de reestruturação escolar imposto pelo governador do estado de São Paulo, contra o qual se mobilizaram os estudantes secundaristas, levaria ao fechamento de ao menos 94 escolas, e traria mudanças no cotidiano escolar que afetariam profundamente a comunidade acadêmica (inclusive familiares) de pelo menos 300 mil estudantes (Campos; Medeiros; Ribeiro, 2016).

O sentimento de indignação dos estudantes secundaristas paulistas se iniciou no cotidiano escolar, sendo coletivizado e difundido pelas redes sociais, principalmente por meio do Facebook e em grupos do WhatsApp. Ao perceberem que essa indignação era compartilhada, os estudantes trouxeram à tona o movimento que começou com protestos locais (contra as diretorias), que se transformavam em passeatas pelos bairros e protestos nas regiões mais centrais (estes reunindo diversas escolas) e em pouco tempo davam início às ocupações (Ortellado, 2016). Esse seria o começo do movimento que chegaria a ocupar mais de 200 escolas por todo o estado de São Paulo no ano de 2015. Segundo Pablo Ortellado (2016), esta teria sido não apenas uma vitória dos estudantes, mas uma das mais importantes derrotas do governador Geraldo Alckmin (PSDB).

As ocupações eram mobilizadas em grande parte por estudantes não organizados, mas também contaram com a participação de organizações de movimentos estudantis, partidos políticos e coletivos. Estes últimos são destacados neste artigo, uma vez que um deles ganhou 
grande visibilidade através do uso das redes e na atuação das ocupações: "O Mal Educado", um grupo sem vinculações partidárias com integrantes que se reconhecem como autônomos e que usam táticas libertárias. Como será abordado ao longo do artigo, a concepção sobre coletivo tem como característica aspectos mais flexíveis e menos engessados. De forma geral, os coletivos têm proximidades com uma perspectiva libertária, com organização horizontal e identificando-se como autônomos. Neste mesmo sentido, têm menos proximidade com partidos políticos e movimentos sociais tradicionais, tendo objetivos de curto prazo marcados pela ação direta, sendo o uso das redes digitais também fundamentais para sua estruturação (Gohn, 2017; Perez; Souza, 2017).

A partir da percepção da grande importância deste movimento no cenário estadual e nacional, e da relevância do uso das TICs ao longo do movimento dos secundaristas em 2015, o presente trabalho se focou no uso das redes sociais, especialmente o Facebook, com a análise das páginas "O Mal Educado" e "Não Fechem Minha Escola"”, visando analisar a importância do uso das redes sociais e realizar um comparativo entre o uso de tais redes por coletivos e outras formas de organização. A escolha das duas páginas se dá pelo fato de que estas produziram e reproduziram conteúdos sobre as ocupações de um modo geral, sem foco em nenhuma escola específica, além de concentrarem grandes quantidades de seguidores. $\mathrm{O}$ coletivo "O Mal Educado", que gerencia a página de mesmo nome, também evidencia sua importância pela tradução e compartilhamento da cartilha "Como Ocupar Um Colégio 3 " e pela influência exercida no início dos protestos. A "Não Fechem Minha Escola" se tornou a página com maior número de curtidas, tendo sido criada ao longo das manifestações secundaristas. É administrada por ativistas autônomos (muitos deles organizados em coletivos, como o Juntos, ou parte da Rede Emancipa) que não se organizaram em coletivo, como é o caso do "O Mal Educado".

Além da revisão bibliográfica que dá bases para a discussão do movimento de ocupações das escolas no estado de São Paulo, esta pesquisa se baseou em entrevistas com integrantes do coletivo "O Mal Educado" e com dois administradores da página "Não Fechem Minha Escola". Tendo como objeto tais páginas de Facebook, foram realizadas ainda a coleta e a análise de conteúdo de publicações de ambas as páginas. Em agosto de 2020, a página do

\footnotetext{
${ }^{1}$ Disponível em https://www.facebook.com/mal.educado.sp/

${ }^{2}$ Disponível em https://www.facebook.com/naofechemminhaescola/

${ }^{3}$ Esta cartilha foi produzida por estudantes chilenos durante a "Revolta dos Pinguins", que aconteceu no Chile no ano de 2006, quando estudantes de várias partes do país protestaram contra o Governo por conta do aprofundamento da privatização da educação. Como forma de luta, os estudantes fizeram protestos nas ruas e posteriormente ocuparam escolas por todo território nacional. O nome "pinguim" foi utilizado, pois os estudantes chilenos são conhecidos assim por conta de seus uniformes que se assemelham com a figura do animal (Zibas, 2008).
} 
"O Mal Educado" concentrava 74.119 seguidores, enquanto a "Não Fechem Minha Escola" apresentava 226.573 seguidores. O trabalho tem como objetivo analisar a importância do uso das redes sociais e realizar um comparativo entre o uso de tais redes por coletivos e outras formas de organização. Para isso, foram analisadas as 50 publicações mais engajadas das duas páginas analisadas, do início das ocupações até o começo da desocupação depois da revogação do projeto de reestruturação escolar feita pelo governador de São Paulo, Geraldo Alckmin, ou seja, do dia 05 de novembro até 10 de dezembro de 2015.

Dessa forma, buscou-se compreender as diferenças e semelhanças na estratégia de atuação nas redes sociais dos coletivos e dos ativistas administradores de página não organizados entre si, bem como no alcance conseguido por estes, através dos conteúdos publicados pelas páginas no mesmo período. Para isso, buscou-se observar se há algum padrão no estilo de suas publicações (fotos, vídeos, notícias compartilhadas, textos escritos diretos, etc.) os comparando em relação às duas páginas.

O artigo está organizado em quatro seções, além desta introdução. A primeira é composta por um debate teórico acerca dos coletivos, tendo como base as teorias dos chamados novíssimos movimentos sociais e contextualizando sua emergência no Brasil. A segunda descreve a relação dos coletivos com as redes, com foco no "O Mal Educado", que administra a página de mesmo nome, analisada neste artigo. A seção três traz os resultados da análise comparativa das páginas, incluindo considerações metodológicas. Por fím, são apresentadas as conclusões, que evidenciam as semelhanças e diferenças na forma de uso das redes sociais pelo coletivo "O Mal Educado" em comparação com a página "Não Fechem Minha Escola”, entendendo que ambas tiveram maior atuação no mesmo período e trataram da mesma temática: a luta dos secundaristas contra a reorganização escolar.

\section{Coletivos: definições a partir dos novíssimos movimentos sociais}

Como visto em manifestações em todo o mundo desde a crise econômica mundial de 2008, passou a ser impossível ignorar a internet e suas ferramentas que passaram a estar presentes em qualquer manifestação da sociedade civil. Manuel Castells (2013) mostrou com detalhes muitos desses movimentos pelo mundo e em todos viu como central o papel das redes. Estes movimentos foram chamados pelo autor de "redes de indignação e esperança", e foram afetados pelo novo ambiente de comunicação, o que trouxe impactos nas novas relações de poder na sociedade (Castells, 2013). 
Na perspectiva de Castells (2013) os principais movimentos sociais que surgiram no mundo a partir desse momento tiveram influência das redes nas suas próprias organizações, já que se colocam como movimentos autônomos, dando pouca centralidade para movimentos sociais mais tradicionais e instituições políticas como partidos ou sindicatos. Pela primeira vez se via em diversas partes do mundo grandes movimentos organizados a partir das redes sociais e com uso intenso das novas tecnologias.

Para Maria da Glória Gohn (2017:24) as novas tecnologias com foco na internet e nos aparelhos móveis são as grandes geradoras do potencial de mobilização da sociedade civil na atualidade, sendo que estas "[...] criam novas formas de sociabilidade longe das estruturas estatais institucionalizadas". É dando centralidade a essas tecnologias que Gohn traz a ideia de "Novíssimos Movimentos Sociais", que surgem na era da internet, sendo mais plurais, autônomos e horizontais, também por influência das estruturas tecnológicas utilizadas.

No Brasil, o movimento que surgiu nesse contexto, segundo Castells (2013), foram as chamadas Jornadas de Junho de 2013, que para Gohn (2017), é o primeiro e principal movimento "novíssimo" no país. As Jornadas de Junho já começaram a partir de um grupo libertário, contrário a hierarquias e instituições políticas tradicionais, o Movimento Passe Livre (MPL) ${ }^{4}$, e ganhou enormes proporções depois de episódios de violência por parte de forças repressoras do Estado. Ao longo do processo das chamadas Jornadas de Junho, o movimento que começou de um grupo libertário e autônomo, mas também com a participação de movimentos sociais mais tradicionais e partidos de esquerda menos hegemônicos (como MTST, PSTU, PSOL, etc.) ampliou-se no número de partidos, entidades institucionalizadas, mas também a população não organizada.

Grande proporção desses protestos se deu com a força das redes sociais e principalmente dos aparelhos móveis (Gohn, 2017). A partir daí foram expostas diversas demandas. Além disso, havia pouca confiança em partidos políticos (por vezes desconfiança, inclusive) e uma organização horizontalizada, em grande medida. Para Ângela Alonso (2016), esse período no Brasil pode ser chamado de "a novidade" de 2013, tendo um repertório autonomista e de movimentos por justiça global, repaginando signos e slogans anarquistas. Além disso, trouxeram um estilo de vida alternativo, sem hierarquia de gêneros, compartilhamento de objetos e espaços, organização descentralizada, deliberação a partir de consensos e ações performativas diretas (black bloc), lutando contra símbolos de poderes, do

\footnotetext{
${ }^{4}$ O Movimento Passe Livre (MPL) se denomina como autônomo, apartidário, horizontal e independente e tem como luta principal a gratuidade do transporte público para todos e com qualidade. Disponível em https://www.mpl.org.br/
} 
capital ao político. Essa "novidade" se deu em contraposição ao repertório socialista anterior marcado por bandeiras vermelhas, megafones e organização vertical.

Maria da Glória Gohn (2017) pontua que o tipo de organização cada vez mais presente que se relaciona com sua descrição sobre os "novíssimos movimentos sociais" são os chamados "coletivos". Segundo a autora, a juventude que tem se articulado nos últimos anos têm maior predisposição a uma organização em coletivo ao invés de movimentos sociais mais tradicionais. Essa preferência se daria porque os jovens veem a estrutura tradicional de movimento social como muito engessada e centralizadora, diferente da concepção de coletivo como sendo de grupos mais fluidos, fragmentados e que tem a autonomia e a horizontalidade como valores e princípios básicos (Gohn, 2017). Nesse sentido: “Coletivos autodenominamse como ativistas, e não militantes de causas, vivem experiências e experimentações que podem ser tópicas ou mais permanentes; fragmentadas ou mais articuladas" (Gohn, 2017:23). Assim, percebe-se que a flexibilidade desses novos tempos se encaixa no formato de organização desses movimentos.

Gretha Leite Maia (2013) traz a importância da articulação de jovens para o crescimento dos coletivos, marcados pela pluralidade de interesses, mobilizações de massas e lideranças horizontais, e também percebeu a crescente importância do uso de tecnologias de informação e comunicação por esses grupos, identificado como relevante nas grandes manifestações por todo o mundo e, no Brasil, com maior força a partir de 2013. Mesmo com as bases libertárias e mais autônomas tendo vindo para os movimentos sociais desde pelo menos Maio de 1968 na França, muito dessa perspectiva passou a ser visto mais recentemente em diversos movimentos pelo mundo, sendo potencializada a partir do uso das novas tecnologias de comunicação e informação (Maia, 2013).

A espontaneidade dos coletivos, vista como fundamental por esses movimentos que se identificam como plurais e não engessados, pode também ser colocada como fraqueza, como identificado em entrevista a um integrante de coletivo por Maia (2013), uma vez que isso acaba trazendo dificuldades para manter um registro formal da existência destas organizações. Essas questões são fundamentais para demonstrar que contradições existem e que os próprios coletivos enxergam não apenas as potencialidades e vantagens de seus mecanismos de atuação, mas também problemas, demonstrando a importância de se avaliar de forma complexa essas discussões.

Conforme Maia (2013), o que distingue os coletivos dos outros movimentos é o fato justamente de o coletivo não ter uma pauta permanente de ação, de modo que ele "pode agregar múltiplas demandas, e, por meio de debates periódicos, são definidas quais as pautas 
prioritárias, a partir da conjuntura política que é mantida em permanente análise.” (Maia, 2013:69). Por este motivo, os coletivos “[...] não visam ter continuidade, só o prazer momentâneo atendendo aos apelos das redes sociais" (Gohn, 2017:27). Nesse mesmo sentido, conforme Maia (2013), os coletivos realizam atividades espontâneas que podem ser interpretadas com uma vantagem, à medida que permitem a construção e novos debates a cada reunião. E essa gênese de transformações constantes é encontrada em muitas das manifestações de juventude analisadas desde pelo menos as grandes movimentações ocorridas por todo o mundo na década de 2010.

Augusto, Rosa e Resende (2016) abordam de forma crítica a visão monolítica como é colocada a categoria de "jovens" dentro das práticas discursivas modernas, pois com essa visão muitas vezes são excluídas questões da ordem das desigualdades sociais e políticas “[...] fazendo que se ignore como se experimenta de formas diversas, essa fase da vida, em classes sociais diferentes" (Augusto; Rosa; Resende, 2016:22). Talvez por esse mesmo motivo que muitos desses "jovens" estão mais envolvidos em coletivos, em que se pressupõe maior flexibilidade, menos hierarquia e de fato uma maior autonomia entre seus participantes. Nesse sentido, os autores afirmam:

\footnotetext{
Embora sejam distintas as concepções de política e de resistência, assim como também são distintas as suas táticas de enfrentamento, os jovens contestadores cada vez mais buscam coletivos e associações não institucionalizados, recusando as disputas por hegemonia que caracterizam as práticas de sindicatos e partidos políticos (Augusto; Rosa; Resende, 2016:25).
}

Mesmo com diferenças e especificidades, os autores aqui analisados possuem algumas noções em comum sobre os coletivos. Um ponto fundamental é que nenhum deles vê o “coletivo" como uma concepção fechada. Em uma visão geral, fica perceptível a importância das manifestações de 2013, da autonomia, da flexibilidade de lutas, do o uso constante das novas tecnologias de informação e comunicação e da horizontalidade (Augusto; Rosa; Resende, 2016; Gohn, 2017; Maia, 2013; Neto, 2018; Peralva et al., 2017; Perez; Souza, 2017). Em um trabalho de análise de 100 coletivos por todo o Brasil, Fernando Lima Neto (2018) reconhece o aumento cada vez mais significativo desse formato de organização, em sua percepção motivado por uma necessidade de maior representatividade e participação direta na política. Em trabalho feito por Perez e Souza (2017) também são analisados alguns coletivos, cujas principais lutas são identitárias, com foco no feminismo e também no movimento negro. Porém, os autores concluem que existem tantas divergências entre os coletivos que não seria possível reuni-los como uma unidade. 
É possível perceber que dentro dessas características gerais sobre coletivos colocadas pelos autores, existe muita relação com a atuação histórica de ações anarquistas (Augusto; Rosa; Resende, 2016). Para Richard Day (2005), os novíssimos movimentos sociais não necessariamente estão configurados como movimentos anarquistas, mas são movimentos anárquicos em relação às suas táticas de ação. Nesse sentido, Augusto, Rosa e Resende (2016) defendem que de fato existe uma multiplicidade de práticas coletivas nos chamados novíssimos movimentos sociais, e seria até contraditório afirmar que todos podem ser colocados como de táticas anarquistas. O mais importante seria "[...] notar a tendência a intervenções na vida cotidiana, em hábitos e percepções sociais que extravasam demandas que possam ter relação com o Estado" (Augusto; Rosa; Resende, 2016:26), assim, a ideia do processo e da maneira da luta se tornam tão decisivos quanto o próprio objetivo de tal luta.

O momento posterior às Jornadas de Junho de 2013 foi bastante importante para os "novíssimos movimentos sociais", que tiveram algumas de suas demandas iniciais concretizadas, como a revogação do aumento das passagens nas capitais do Brasil e também em outras cidades. Também neste período se iniciou o que Alonso (2016) chama de "Ciclo Patriota”, que teve como marco inicial manifestações contra o PT nos meses de março e abril de 2015. Pela "conjuntura fluida" trazida pelo ciclo de 2013 passou a se ter um ambiente instável que vinha se alimentando desde o julgamento do "Mensalão", estimulando assim um espírito de "faxina ética" da imprensa e da opinião pública (Alonso, 2016). Nesse período, surgem movimentos mais conservadores, também com força das redes, como o "Vem Pra Rua", o "Movimento Brasil Livre" (MBL) e o bastante reacionário "Revoltados Online". Todos esses, segundo Gohn (2017), podem ser analisados na cortina dos "novíssimos movimentos sociais".

Além de tais movimentos mais conservadores, Junho de 2013 pode também ser considerado base para movimentos reivindicatórios do campo mais progressista, como foi o caso da expansão dos movimentos feministas com a chamada "Primavera Feminista" (Pinheiro-Machado, 2019) e também do movimento secundarista em São Paulo no ano de 2015. Este movimento surgiu de forma autônoma pelos secundaristas do estado de São Paulo depois da proposta de reorganização, que seria imposta pelo governo de São Paulo em um período de tempo muito pequeno. Também para Januário et al. (2016) o movimento dos secundaristas pode ser visto como uma das continuidades de 2013, principalmente na primeira fase daquele ano com a participação mais forte do MPL, por conta 
[...] do caráter explosivo e inesperado; a centralidade da ação direta; uma nova forma de fazer política, de caráter horizontal e que não passa pelos partidos políticos; a importância das redes sociais; e um formato da luta social que pode ser entendido como "negativo". Com esta última afirmação queremos dizer que, em ambos os casos, não se tratava de uma negociação em moldes tradicionais por caminhos institucionalizados e nem de propor uma luta ofensiva (que reivindicasse imediatamente a "tarifa zero" ou a "educação pública de qualidade"), mas sim de barrar medidas governamentais e quebrar seus discursos tecnocráticos (Januário et al., 2016:01).

O movimento secundarista começou pela indignação primeiramente local, compartilhada pelas redes sociais, ganhando assim uma força cada vez mais descentralizada (Ortellado, 2016). Por estarem sempre utilizando as redes como instrumento fundamental de luta, criando muitas hashtags, publicações, abaixo-assinados, além de diversos comentários nas páginas de Facebook das escolas e seus grêmios - inclusive na página oficial da Secretaria de Estado da Educação (Januário et al., 2016) - rapidamente as passeatas locais se unificaram e ganharam mais intensidade. Com a organização e discussões tanto em rede quanto em assembleias locais, percebendo que as passeatas não estavam tendo o impacto esperado - durante 6 semanas foram mais de 200 manifestações (Januário et al., 2016) começaram a pensar em táticas mais radicais.

Neste contexto, aparece em cena a cartilha dos secundaristas do Chile em 2006, ("Revolta dos Pinguins") e da Argentina, com a tradução feita por um coletivo autônomo, "O Mal Educado", tendo este grande participação de militantes do MPL (segundo entrevistado do coletivo "O Mal Educado", exceto por ele e sua companheira todos os integrantes do coletivo, a princípio, eram parte do $\mathrm{MPL}^{5}$ ). Esta cartilha foi distribuída nas redes (principalmente por meio de grupos do WhatsApp e Facebook), e apresentada a estudantes de maneira impressa em meio aos primeiros protestos contra a reorganização escolar. Tal cartilha, com o nome “Como Ocupar um Colégio?" foi fundamental para as primeiras ocupações, que posteriormente chegaram a mais de 200 escolas por todo o estado. A partir desse momento, o coletivo "O Mal Educado" passa a ter uma maior importância no movimento, principalmente pelo compartilhamento de informações e outras cartilhas divulgadas em sua página pelo Facebook.

\footnotetext{
${ }^{5}$ OME (2020). Entrevista concedida por integrante do coletivo O Mal Educado [ago. 2020]. Entrevistadores: os autores. Google Meets. 1 arquivo. mp4 (102 min).
} 


\section{Coletivos e Redes: O Mal Educado}

Durante as ocupações das escolas, o uso das redes e das tecnologias, principalmente a partir dos aparelhos móveis, foi se mostrando fundamental tanto para a divulgação rápida de informações entre as diferentes ocupações, quanto para o resto da população, notificando os acontecimentos de uma forma independente em relação aos veículos da imprensa tradicional, servindo ainda como instrumento de segurança em situações de perigo frente à polícia ou outras forças repressoras (Campos; Medeiros; Ribeiro, 2016). Nesse sentido, foram criadas diversas páginas específicas das escolas ocupadas nas redes sociais, além de outras mais gerais, como foi o caso da "O Mal Educado" e da "Não Fechem Minha Escola", sendo esta a página com maior acesso.

Segundo Romancini e Castilho (2017), os estudantes e os apoiadores utilizaram diversos serviços de tecnologia digitais (como WhatsApp, Twitter, Instagram, etc.), mas foi o Facebook a principal rede social para mobilização com a criação das mais diversas páginas. Segundo análise produzida pelos autores, em um total de 219 escolas ocupadas no estado, pelo menos 50 criaram uma página específica de sua ocupação no Facebook, principalmente as da capital (Romancini; Castilho, 2017). Na análise os autores ainda perceberam que a maioria das postagens tinha como objetivo mostrar o cotidiano das ocupações e em segundo lugar impulsionar a mobilização (Romancini; Castilho, 2017).

As ocupações foram organizadas de forma autônoma e horizontal, a partir de assembleias e divisão de tarefas por comissões. No geral, contavam com comissões diversas, sendo elencadas no manual "Como ocupar um colégio?" como necessárias as de: Comida, Segurança, Imprensa, Informação, Limpeza, Relações Externas, Assembleias e Atividades. Em relação à comunicação, as comissões de Imprensa e Informação se voltariam para esta atividade: aquela para comunicação com os veículos de notícias, e esta para constituir uma comunicação própria, nas páginas de Facebook, por exemplo.

Este foi o caso da E.E. Maria José, na capital de São Paulo, que criou uma página no Facebook de nome "Ocupação Maria José”. Segundo um dos estudantes: "A gente filma, tira foto, faz publicação na página do Facebook que é na página 'Ocupação Maria José' e a gente também pega depoimentos de pessoas que vão mudar de escolas, e também daquelas que não vão, mas apoiam de alguma forma, colocamos nas redes sociais" (Anjos Rebeldes, 2015) relato que evidencia a função dessas páginas e a importância das redes para as ocupações. Além das páginas específicas de cada escola ocupada, outras páginas voltadas para as ocupações foram criadas e/ou utilizadas. A análise deste artigo se foca em duas das principais 
páginas de caráter mais geral da luta dos estudantes secundaristas: "O Mal Educado", criada e administrada pelo coletivo "O Mal Educado"; e "Não Fechem Minha Escola", criada por ativistas independentes para funcionar como um centralizador de informações acerca das ocupações.

A origem do Coletivo "O Mal Educado" vem de 2009, quando estudantes da Escola Estadual José Vieira de Moraes (o Vieira), do bairro Rio Bonito - distrito da Cidade Dutra, no extremo sul de São Paulo - mobilizaram-se contra a diretora da escola, considerada uma pessoa bastante rígida. Os alunos começaram a se organizar pelo clima de revolta generalizada, com grandes protestos. Nesse período surgia uma articulação que acabaria se tornando a "Poligremia", que segundo o membro do Mal Educado (informação verbal) ${ }^{6}$, era uma junção de grêmios estudantis de escolas particulares que ficaram sabendo da luta do Vieira e quiseram ajudá-los, auxiliando na criação de um jornal para falar sobre luta e organização estudantil. No ano de 2010, a Poligremia foi se expandindo ${ }^{7}$.

Em 2012, quando grande parte dos membros da Poligremia já estavam na Universidade e em grande medida militava no Movimento Passe Livre (MPL), como afirma o entrevistado do Mal Educado, estes,

\begin{abstract}
chamam uma reunião para pensar em boletim, alguma coisa do tipo assim, e aí eles me convidam, isso em 2012. E aí a partir daí a gente tira a primeira edição do jornal O Mal Educado. Portanto, era basicamente um jornal editado por ex-secundaristas e o jornal era uma forma de a gente conseguir ter entrada nas escolas para fazer atividades e discutir questões que a gente tratava no nosso jornal. (Informação Verbal $)^{8}$
\end{abstract}

A experiência do Poligremia, com uma perspectiva mais horizontal e participativa, foi importante para o coletivo, que passou a se aproximar das lutas contra o aumento da tarifa de ônibus do Movimento Passe Livre (MPL) ainda em 2011. Já nesse período faziam exibições do documentário "A Rebelião dos Pinguins", de Carlos Prozato, sobre a mobilização de estudantes secundaristas no Chile, em 2006, conhecida como Revolução dos Pinguins (Campos; Medeiros; Ribeiro, 2016).

\footnotetext{
${ }^{6}$ OME (2020). Entrevista concedida por integrante do coletivo O Mal Educado [ago. 2020]. Entrevistadores: os autores. Google Meets. 1 arquivo .mp4 (102 min).

${ }^{7}$ Participaram da Poligremia Grêmios das escolas particulares: Escola da Vila, Santa Cruz, Equipe, Vera Cruz, Santa Clara, Oswald de Andrade e Ítaca; das escolas técnicas estaduais: Basilides de Godoy, Guaracy Silveira, ETESP, Albert Einstein, Takashi Morita; uma escola da Rede Sesi (Vila Leopoldina) e a E.E. José Vieira de Moraes (Campos; Medeiros; Ribeiro, 2016).

${ }^{8}$ OME (2020). Entrevista concedida por integrante do coletivo O Mal Educado [ago. 2020]. Entrevistadores: os autores. Google Meets. 1 arquivo .mp4 (102 min).
} 
O coletivo usava constantemente as redes e possuía uma página no Facebook desde 9 de abril de 2013, além de um blog 9 . Com a eclosão do movimento dos secundaristas em 2015, já estavam envolvidos com muitas das escolas e discussões. Com a divulgação, pelas redes, de uma tradução da cartilha "Como Ocupar Um Colégio" a partir da experiência do Chile e da Argentina, o coletivo passou a ter uma maior relevância para o movimento, assim: "O Mal Educado não atuou como dirigente do processo político, mas meramente como um catalisador que detonou uma virada tática - das manifestações de rua às ocupações -, apresentando uma nova forma de ação coletiva, desconhecida ou impensável para os alunos" (Campos et al., 2016:79). Além disso, a página do coletivo no Facebook passou a divulgar informações sobre as ocupações e a luta dos secundaristas, além de publicar outras cartilhas como o "Manual de Como Travar Uma Avenida"10 ou a de "Boicote ao Saresp"11.

Em entrevista, foi questionado ao participante do "O Mal Educado" o motivo de se denominarem coletivo. Para o entrevistado a denominação veio para buscar uma diferenciação em relação aos movimentos sociais tradicionais: "[...] a gente não é uma juventude de uma organização partidária, a gente não é uma entidade estudantil. Então o que a gente é? A gente é um coletivo" (informação verbal) ${ }^{12}$. Neste sentido, salientou ainda que não possuíam documento formal (como um estatuto, ou uma carta de princípios), mas que o que os unia enquanto coletivo era uma semelhança de ideias em relação às questões que se dispunham a pensar: "O que a gente tinha era essa sintonia de pensar parecido, acreditar numa forma de atuação parecida, e tal" (informação verbal) ${ }^{13}$. O coletivo se dissolveu em 2016 (apesar de sua página seguir com algumas publicações), e para o entrevistado isso se relaciona com a falta de evidenciar os princípios, de possuir um direcionamento do coletivo, já que ao fim das ocupações e no início das ocupações das ETECs (Escolas Técnicas Estaduais) ${ }^{14}$, em 2016, as diferenças foram se expressando: "Tipo assim, quando acabou a luta a sintonia

\footnotetext{
${ }^{9}$ Disponível em https://gremiolivre.wordpress.com/

${ }^{10}$ Disponível em https://www.facebook.com/mal.educado.sp/photos/a.301502323316853/726248084175606

${ }^{11}$ Disponível em

https://www.facebook.com/mal.educado.sp/photos/a.301502323316853/723260364474378/?type=3\&theater

12 OME (2020). Entrevista concedida por integrante do coletivo O Mal Educado [ago. 2020]. Entrevistadores: os autores. Google Meets. 1 arquivo .mp4 (102 min).

${ }^{13}$ Ibid.

${ }^{14}$ No ano de 2016, ainda com a força dos movimentos secundaristas ocorridos alguns meses antes, um esquema de desvio e corrupção relacionados à merenda escolar passou a ser investigado pela "operação Alba Branca" envolvendo nomes próximos ao Governador Geraldo Alckmin e ao então presidente da ALESP, Fernando Capez. A pauta da merenda foi um novo impulsionamento para outras ocupações, pelo menos 16 Escolas Técnicas Estaduais (ETECs), o Centro Paula Souza e também a Assembleia Legislativa do Estado de São Paulo (ALESP) (Campos, 2019).
} 
também foi acabando, aí começa a aflorar as diferenças aí você fala 'não, peraí, não era bem isso aí que eu acreditava', e aí começa a surgir diferenças" (informação verbal) ${ }^{15}$.

Além da relevância das redes sociais para a atuação do coletivo, outra característica foi citada: a ação direta, que era compartilhada enquanto forma de atuação principal pelos seus integrantes:

\begin{abstract}
Quando a gente chama a manifestação contra a reorganização a gente quer barrar organização pela manifestação. (...) E isso inclusive é uma coisa que explica um pouco por que que a esquerda em geral não tinha uma estratégia para luta secundarista, por que para eles tanto faz "ah é manifestação, é ocupação, o que for, que seja, tanto faz para mim, que a minha atuação ela vai se dar nos gabinetes, ela não vai se dar aqui". (...) Então essa defesa da ação direta de que aquilo que se faz publicamente (...). A (...) gente nunca ficou preocupado com a legitimidade do comando das escolas, por exemplo, para representar os estudantes, porque a representação só é importante caso você fosse negociar com governo. (Informação verbal) ${ }^{16}$.
\end{abstract}

O coletivo "O Mal Educado" chegou a contar com 3 participantes, mas também teve reuniões com 40 pessoas engajadas. Pode-se observar uma noção de trânsito pelo coletivo, que não havendo estatuto ou filiação, como em organizações partidárias, contou com maior ou menor quantidade de participantes dependendo do período.

\title{
A página "Não Fechem Minha Escola"
}

De acordo com entrevista realizada com administradores da página "Não Fechem Minha Escola" (sendo um deles o criador, no período das ocupações), esta foi criada a partir da sensação de que as mobilizações nasceram bastante organicamente nas escolas, mas estavam desarticuladas. Neste sentido, entenderam "que o movimento precisava ter alguma unificação para conseguir demonstrar força" (informação verbal) ${ }^{17}$. Criaram a "Não Fechem Minha Escola", em 3 de outubro de 2015, para reunir as informações das diferentes ocupações e mobilizações do estado de São Paulo.

Esta página foi um instrumento essencial para vários dos estudantes secundaristas se organizarem e ocuparem as escolas. A "Não Fechem Minha Escola" mostra sua importância especialmente pela visibilidade, já que agrega grande número de seguidores. No período das ocupações, eram publicados vídeos, fotos, notícias e textos sobre os acontecimentos relacionados. Hoje, ainda bastante ativa, a página continua mapeando protestos de estudantes

\footnotetext{
${ }^{15}$ OME (2020). Entrevista concedida por integrante do coletivo O Mal Educado [ago. 2020]. Entrevistadores: os autores. Google Meets. 1 arquivo .mp4 (102 min).

${ }^{16}$ Ibid.

${ }^{17}$ NFME1 (2020). Entrevista concedida por criador e administrador da página Não Fechem Minha Escola [ago. 2020]. Entrevistadores: os autores. Google Meets. 1 arquivo .mp4 (43 min).
} 
secundaristas e publica ainda conteúdos relacionados ao cenário político mais macro, incluindo publicações sobre as eleições, por exemplo. Como membros da equipe, constam na página do Facebook os nomes de Rafael Borguin, Gabriel Lindenbach e Sâmia Bomfim - esta eleita vereadora de São Paulo em 2016 e deputada federal em 2018.

Segundo o criador da página (informação verbal) ${ }^{18}$, a "Não Fechem Minha Escola" contava com grande número de colaboradores (chegando a cerca de 30, em dado momento), que passavam a compor a administração da página por serem bastante ativos no envio de informações. Os administradores se organizavam em um grupo de mensagens instantâneas (Messenger), onde cada um encaminhava as possíveis publicações e, não havendo restrições por parte dos outros integrantes, a informação era publicada.

O nome da página é assunto de debate. Segundo o criador e administrador da "Não Fechem Minha Escola", o nome surgiu do clamor das e dos estudantes que se organizavam nas ocupações, em oposição à reorganização, e da necessidade de uma fonte de informação unificada para fortalecê-los (informação verbal) ${ }^{19}$. Para o entrevistado do coletivo "O Mal Educado", a criação da página com o slogan das e dos estudantes aparece como problemático, uma vez que passava a ideia de que ali estava contido todo o movimento (informação verbal $)^{20}$. Ainda para este, a "Não Fechem Minha Escola" era organizada por um coletivo, o Juntos, com forte vinculação ao Partido Socialismo e Liberdade (PSOL), o que é negado pelo administrador da página, que apesar de compor o coletivo no período em questão, não vincula a página a ele, uma vez que esta era administrada por diversas pessoas, muitas delas não vinculadas ao Juntos.

\section{Análise das páginas “O Mal Educado" e "Não Fechem Minha Escola"}

No dia 5 de novembro de 2015, os estudantes da Escola Estadual Diadema ocuparam sua escola, e no início do dia seguinte, os estudantes da tradicional Escola Estadual Fernão Dias, na cidade de São Paulo, também o fizeram. A partir daí, as ocupações cresceram. Muitas delas foram cercadas por batalhões da Polícia Militar e da Tropa de Choque para reintegração de posse. Além disso, os estudantes sofreram pressão judicial e foram duramente criticados (e por vezes caluniados, segundo eles próprios) pelos veículos de imprensa

\footnotetext{
${ }^{18}$ NFME1 (2020). Entrevista concedida por criador e administrador da página Não Fechem Minha Escola [ago. 2020]. Entrevistadores: os autores. Google Meets. 1 arquivo .mp4 (43 min).

${ }^{19}$ NFME1 (2020). Entrevista concedida por criador e administrador da página Não Fechem Minha Escola [ago. 2020]. Entrevistadores: os autores. Google Meets. 1 arquivo .mp4 (43 min).

${ }^{20}$ OME (2020). Entrevista concedida por integrante do coletivo O Mal Educado [ago. 2020]. Entrevistadores: os autores. Google Meets. 1 arquivo .mp4 (102 min).
} 
tradicionais. Em menos de um mês as ocupações atingiram 200 escolas por todo o estado e o apoio de intelectuais, artistas e da população cresceu em uma taxa cada vez maior.

$\mathrm{O}$ uso das TICs se destacou ao longo desse processo, inclusive durante as próprias ocupações, criando uma espécie de ambiente híbrido, nos termos de Castells (2013), entre as ocupações dos espaços físicos e o ambiente virtual, que se complementavam mutuamente. $\mathrm{O}$ uso intensivo de TICs serviu como um mecanismo de defesa contra a imprensa tradicional, as forças policiais e outras instituições que, a partir da divulgação de informações falsas ou negativas sobre os protestos, buscaram intimidar os estudantes. Os secundaristas envolvidos nos protestos utilizaram as redes sociais como um canal de divulgação de informações próprias, visando angariar apoio de usuários e de mídias independentes (Campos; Medeiros; Ribeiro, 2016).

Nessas ações podemos observar uma intensa utilização das TICs de forma autônoma e como instrumento fundamental de luta e organização para suas atividades cotidianas, o que Manuel Castells (2013) chama de autocomunicação. Quando essa autocomunicação chega às massas, oferece uma plataforma tecnológica para a construção de autonomia do ator social, afirma o autor.

As mídias digitais serviram como um agente de organização para as ações dos secundaristas nas ruas e nas redes, assim como articularam protestos como o Occupy em diversas cidades dos EUA e o 15M (Indignados) na Espanha. O compartilhamento de conteúdo altamente personalizado por meio de mídias digitais ligadas às ocupações permitiu que informações referentes aos protestos pudessem circular rapidamente e atingir os usuários interessados nas pautas, fortalecendo os protestos a partir de uma ação conectiva (cf. Bennett; Segerberg, 2012) que não exige uma identificação institucional de seus participantes ou recursos em níveis organizacionais. A ação digital em rede (Gerbaudo, 2014) empreendida pelos secundaristas colabora com a tendência de jovens ativistas se distanciarem de grupos de identificação coletiva como partidos políticos e sindicatos, e obteve êxito em configurar uma identidade coletiva não restrita a estudantes, mas sim a todos os cidadãos que defendem educação pública, gratuita e de qualidade.

Veem-se, dentro desta perspectiva, características essenciais no que Maria da Glória Gohn (2017) chama de "Novíssimos Movimentos Sociais", pois tais movimentos são marcados pela autonomia, horizontalidade, ação-direta e o uso intenso das novas tecnologias da informação e comunicação, com isso, uma maior desconfiança por partidos políticos ou grupos já institucionalizados de poder, mas não excluindo estes totalmente, como foi possível perceber ao longo do período de ocupações de escolas em São Paulo. Massimo Di Felice 
(2017), ao abordar sobre tais movimentações sociais contemporâneas, os chama de movimentos "net-ativistas" por considerá-los a partir das caracterizações antes citadas, mas também uma ação conectiva mais complexa, em que as ocupações de espaços físicos e a ocupação das redes digitais são necessárias e se complementam mutuamente sem diferenças de importância, sendo ambas essenciais para os atos como um todo.

\section{Considerações metodológicas}

A fim de compreender as estratégias de comunicação adotadas pelas páginas ligadas aos protestos de estudantes secundaristas, foi analisado o conteúdo de publicações postadas e foram realizadas entrevistas com figuras responsáveis por administrá-las. A análise de conteúdo deste trabalho permite uma abordagem integral da mensagem à medida que considera todos os elementos presentes no post, textuais ou não, e possibilita o entendimento da informação que o autor busca transmitir, a partir da verificação dos assuntos presentes em cada publicação e da orientação de sua transmissão. Ao articular a análise de conteúdo das mensagens publicadas em suas páginas no Facebook com as afirmações realizadas pelos integrantes desses grupos em entrevistas, pode-se compreender e verificar a estratégia comunicativa utilizada por eles no meio online.

O coletivo "O Mal Educado" gerenciava a própria página no Facebook enquanto a página "Não Fechem Minha Escola" era gerida por ativistas simpatizantes ao movimento, mas não que eram diretamente conectados a nenhum coletivo específico (alguns eram parte do coletivo Juntos, outros compunham a Rede Emancipa de cursinhos populares, mas a página não se vinculava especificamente a nenhuma dessas organizações). Nesse sentido, é possível identificar as semelhanças e diferenças de abordagens no conteúdo publicado por cada página a partir de mensagens publicadas diretamente por um coletivo organizado e por posts articulados por jovens apoiadores do movimento.

A página do "O Mal Educado" conta, atualmente, com mais de 77 mil curtidas, com raras publicações. Já a página "Não Fechem Minha Escola" conta com mais de 220 mil curtidas, e desde 2015, com as ocupações das escolas em São Paulo, publica conteúdo, se mantendo ativa até hoje. Ambas as páginas funcionavam, no período das ocupações, a partir do recebimento de informações de cada escola via mensagem do Facebook ou WhatsApp e não possuíam diretrizes de publicação.

Em relação à visibilidade de cada página, cabe pontuar que, em entrevista, um integrante do "O Mal Educado" afirmou que na página de Facebook do coletivo nunca 
ocorreram publicações patrocinadas (informação verbal) ${ }^{21}$, enquanto o entrevistado da página "Não Fechem Minha Escola" respondeu que patrocinaram algumas publicações (com recursos de dois dos administradores da página ou de outros grupos, no caso de publicações que envolviam, por exemplo, a ONG Minha Sampa) (informação verbal) ${ }^{22}$.

Durante o mês de abril de 2018, foi realizada uma busca de publicações postadas pelas páginas "O Mal Educado" e "Não Fechem Minha Escola" no Facebook entre 8 de novembro e 10 de dezembro de 2015, por meio da ferramenta de extração de dados Facepager. Foram coletadas 502 publicações a partir da página "O Mal Educado" e 559 publicações a partir da página "Não Fechem Minha Escola 23 ".

Foram selecionadas as 50 publicações de cada página com o maior engajamento entendido nesse estudo como a soma de curtidas, reações, comentários e compartilhamentos postadas no período abordado, totalizando 100 publicações para análise de conteúdo. As mensagens mais engajadas das duas páginas no período variam de um valor de 26.359 (publicação mais engajada no dia 02/12/2015) até o valor de 1.492 (50 publicação mais engajada do período no dia 20/11/2015) no caso da página “O Mal Educado"; e de um total de 56.475 (publicação mais engajada no dia 01/12/2015) até o valor de 4.191 (50 publicação mais engajada no dia 03/12/2015) no caso da página "Não Fechem Minha Escola".

A partir dessa amostra, as publicações de cada página foram analisadas e comparadas entre si a fim de compreender quais conteúdos postados receberam o maior engajamento por parte dos usuários, quais temas foram mais discutidos, quais as semelhanças e diferenças entre o enquadramento das publicações das páginas e quais recursos foram utilizados nesses posts.

A metodologia utilizada foi desenvolvida pelo NEAMP/PUC-SP (Núcleo de Estudos de Arte, Mídia e Política), sistematizada por Bachini et al (2015) e adaptada para este estudo. As publicações são agrupadas nas seguintes categorias: recursos empregados; temas abordados e enquadramento das mensagens. O conceito de enquadramento utilizado neste trabalho segue a noção desenvolvida por Penteado, Santos e Araújo (2009) na qual enquadramento é um componente da análise de conteúdo de uma mensagem e se refere à dimensão de apresentação de uma informação, podendo receber caráter informativo direto,

\footnotetext{
${ }^{21}$ OME (2020). Entrevista concedida por integrante do coletivo O Mal Educado [ago. 2020]. Entrevistadores: os autores. Google Meets. 1 arquivo .mp4 (102 min).

${ }^{22}$ NFME1 (2020). Entrevista concedida por criador e administrador da página Não Fechem Minha Escola [ago. 2020]. Entrevistadores: os autores. Google Meets. 1 arquivo .mp4 (43 min).

23 Os posts da amostra podem não representar a totalidade das mensagens publicadas pelas páginas nesse período, porém devido a uma falha na API do Facebook só foi possível recuperar pouco mais de 1000 publicações por meio do Facepager.
} 
informativo indireto, opinativo, irônico, propositivo, conter uma avaliação moral, uma avaliação crítica e um posicionamento político.

A análise de conteúdo foi realizada a partir de textos, links e recursos audiovisuais identificados nas publicações. Em relação aos recursos, as páginas podem apresentar uso de: fotos (registros fotográficos de pessoas e ambientes), gráficos, charges, vídeos, áudios, imagens (representações gráficas como memes, ilustrações e fotos com alterações digitais), links, imagens $360^{\circ}$, textos, transmissões ao vivo, vídeos $360^{\circ}$ e combinações entre recursos.

As categorias de temas foram definidas a posteriori. Entre os temas foram identificados: Manutenção da escola, Apoio de terceiros, Desinformação, Demandas dos estudantes, Violência policial, Mobilização dos estudantes, Políticas adotadas pelo governo Geraldo Alckmin, SARESP e Popularidade do governador Geraldo Alckmin. Foram classificados com o tema "Manutenção da escola" posts específicos sobre estudantes realizando ações de conservação de infraestrutura das dependências da escola. A categoria "Apoio de terceiros" reúne publicações que apresentam demonstrações de apoio por parte de cidadãos, personalidades, organizações e movimentos sociais. Sob o tema "Desinformação" foram englobados posts que buscavam desmentir ou corrigir informações erroneamente passadas por terceiros, usualmente emitidas pelo então Governador do Estado de São Paulo, Geraldo Alckmin. As publicações classificadas com "Demandas dos estudantes" agregam mensagens que tratam das pautas elaboradas pelos secundaristas. O tema "Violência policial" se refere a posts que reúnem conteúdos sobre abuso de autoridade e atos de violência praticados pela Polícia Militar do Estado de São Paulo contra alunos, professores e cidadãos envolvidos nas ocupações. A categoria "Mobilização dos estudantes" abrange publicações relativas a ocupações bem sucedidas, atos, protestos, marchas realizadas pelos secundaristas e outras ações relacionadas às ocupações. A categoria "Políticas adotadas pelo governo Geraldo Alckmin" se refere a posts que discutem a composição da pasta da Educação no Estado de São Paulo e medidas derivadas do posicionamento político do governador. O tema "SARESP" engloba publicações que discutem a prova do Sistema de Avaliação do Rendimento Escolar do Estado de São Paulo, uma vez que uma das maneiras de se mobilizarem contra a reorganização foi através do boicote à esta prova: em 2015 os manifestantes secundaristas concordaram em realizar um boicote contra o SARESP como forma de protesto contra as políticas educacionais do Governo do Estado de São Paulo. Por fim, a "Popularidade do governador Geraldo Alckmin" é também um tema identificado nas publicações dos coletivos. 
Em relação ao enquadramento, as categorias foram adaptadas a posteriori para servir às dimensões informativas encontradas nas mensagens analisadas. Nesse sentido, as publicações apresentaram conteúdo definido como: informativo, denúncia, ataque ao governador, ataque a críticos, irônico e chamada para mobilização. Na categoria "Informativo", as publicações apresentavam informações e dados sobre acontecimentos ligados às ocupações e essas mensagens poderiam acompanhar vídeos, imagens ou links para ilustrar os dados. Nas publicações classificadas como "Denúncia", as páginas apresentavam notícias sobre ataques às ocupações, alunos, apoiadores e professores. Em "Ataque ao governador" foram identificadas mensagens realizando provocações ou respondendo a ações e posicionamentos do então governador Geraldo Alckmin. A categoria "Ataque a críticos" abrange posts que se dirigiam a opositores das ocupações como outras figuras políticas ou professores. Publicações com enquadramento "Irônico" expõem informações e argumentos utilizados pelos coletivos a partir de uma perspectiva de ironia. Finalmente, posts classificados com enquadramento "Chamada para mobilização" se referem a conteúdos que convocam estudantes e simpatizantes a participar de manifestações e apoiar as ocupações.

\section{Resultados}

A seguir, são apresentados os resultados da análise de conteúdo das publicações da amostra. Algumas publicações apresentam mais de um recurso e são classificadas em uma categoria de combinação entre os recursos a partir da utilização do sinal de adição (+) apresentada nos gráficos. Desse modo, se uma mensagem apresenta uma Imagem e um Texto, será classificada com a categoria "Imagem + Texto".

A partir do Gráfico 1 pode-se identificar que os recursos mais utilizados pela página "O Mal Educado" são as combinações entre "Foto e Texto" e "Vídeo e Texto", representando 27 e 7 posts, respectivamente. Muitas das fotos publicadas retratam as escolas ocupadas ou manifestações dos secundaristas nas ruas e acompanham legendas, enquanto outras publicações listam as escolas ocupadas e acompanham fotos para ilustrar. Diversos vídeos apresentam manifestações de apoio aos secundaristas e também acompanham legendas. A combinação entre "Imagem e Texto" foi identificada em 6 publicações, a categoria "Foto, Link e Texto" estava presente em 4 publicações e a combinação "Vídeo, Link e Texto" se fez presente em 3 posts. As demais combinações foram identificadas em apenas uma publicação cada. 


\section{Gráfico 1}

Recursos utilizados pela página "O Mal Educado"

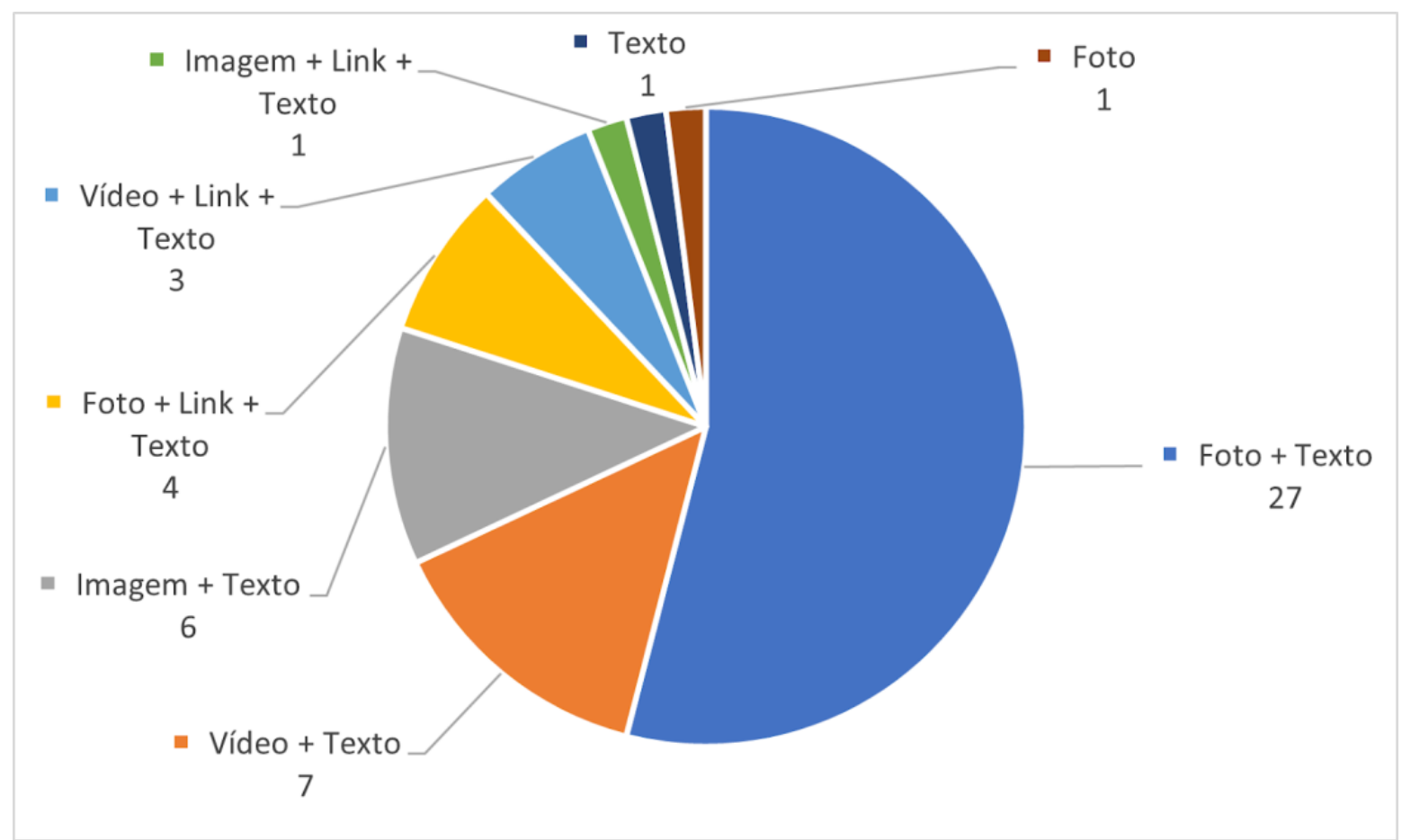

Fonte: Elaboração dos autores.

Como se pode observar no Gráfico 2, as duas combinações mais presentes em publicações da página "Não Fechem Minha Escola" são "Imagem e Texto", categoria que contabilizou 14 publicações, enquanto as combinações "Foto e Texto" e "Vídeo e Texto" foram utilizadas em 11 e 12 posts, respectivamente. A composição dos recursos das publicações se assemelha àquela utilizada pelo coletivo "O Mal Educado" a partir da publicação de fotos de escolas ocupadas e estudantes se manifestando, também apresentando fotos de Geraldo Alckmin e algumas figuras políticas que compunham a pasta da Educação na época. A combinação "Vídeo e Link" foi identificada em 4 posts e a combinação "Imagem e Link" foi identificada em 3 posts. Tanto a categoria "Charge e Texto" quanto "Foto e Link" estavam presentes em 2 publicações. Por fim, "Link e Texto" é uma combinação identificada em apenas um post. 


\section{Gráfico 2}

Recursos utilizados pela página "Não Fechem Minha Escola"

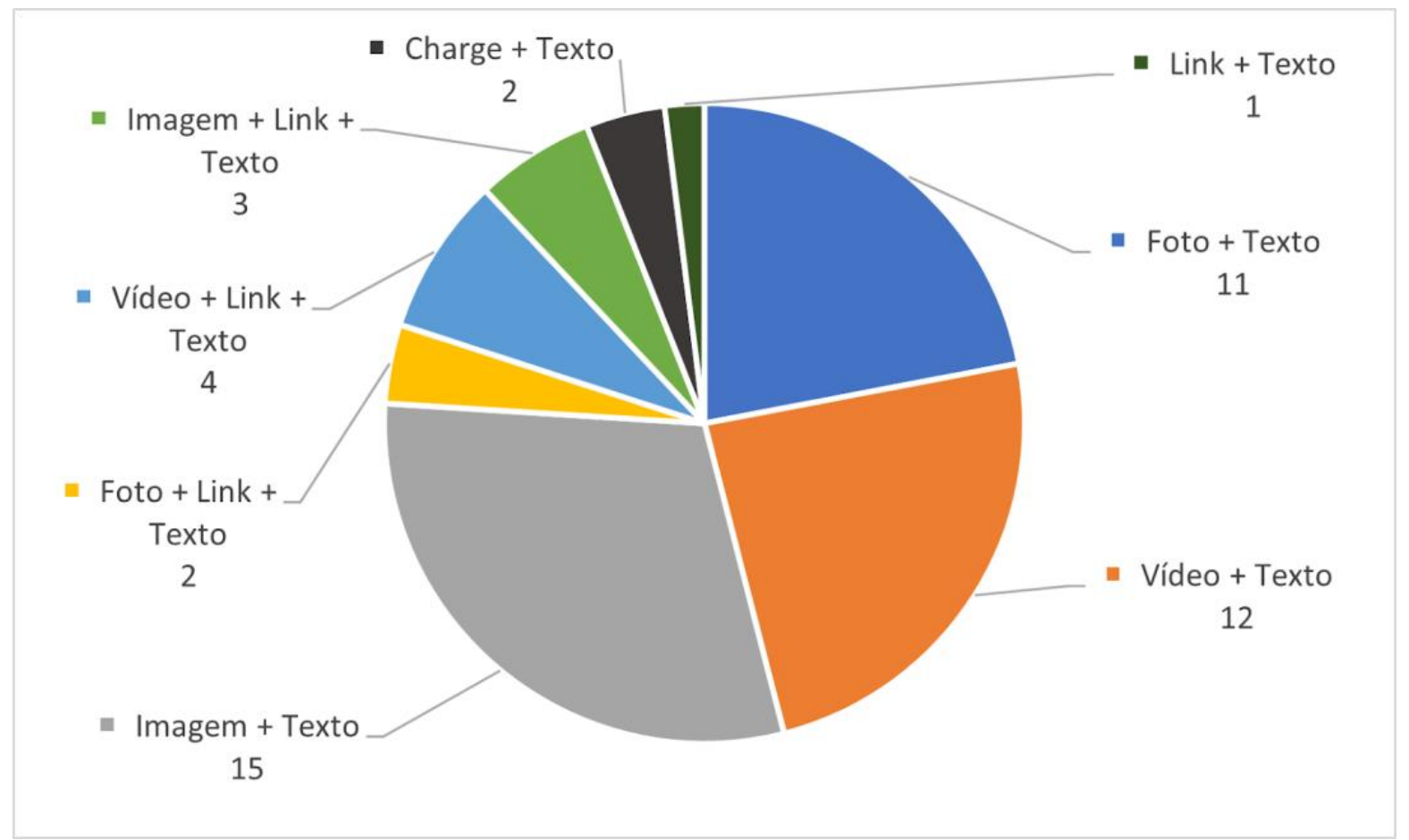

Fonte: Elaboração dos autores.

O Gráfico 3 permite a identificação dos temas mais discutidos nas publicações. Em 22 dos 50 posts analisados, a página "O Mal Educado" comentou sobre mobilizações dos estudantes, seguido por 7 publicações discutindo as demandas dos secundaristas, 6 publicações retratando o apoio de personalidades e cidadãos, assim como 6 publicações expondo casos de violência policial contra estudantes e simpatizantes.

Apesar do tema "Manutenção da escola" ser identificado apenas 4 vezes na amostra, os posts com essa temática apresentaram os maiores números de engajamento entre as mensagens coletadas. Segundo entrevistado do coletivo "O Mal Educado" (informação verbal $^{24}$, uma estratégia adotada pelo coletivo foi a publicação de posts com temática de manutenção da escola, mostrando alunos limpando, cozinhando e arrumando suas escolas, a fim exibir a realidade das e dos estudantes secundaristas que ocuparam aquelas instituições de ensino, e, a partir de uma visão estratégica, angariar maior apoio da opinião pública. O tema "Desinformação" engloba publicações que buscavam corrigir informações e dados disseminados pelo Governo do Estado de São Paulo e por mídias de notícias como a Rede

${ }^{24}$ OME (2020). Entrevista concedida por integrante do coletivo O Mal Educado [ago. 2020]. Entrevistadores: os autores. Google Meets. 1 arquivo .mp4 (102 min). 
Globo sobre o plano de reorganização e a situação das ocupações, compondo 2 posts, assim como a categoria "Políticas adotadas pelo governo Geraldo Alckmin". Uma dentre as 50 publicações dizia respeito ao SARESP.

\section{Gráfico 3}

Temas abordados pela página "O Mal Educado"

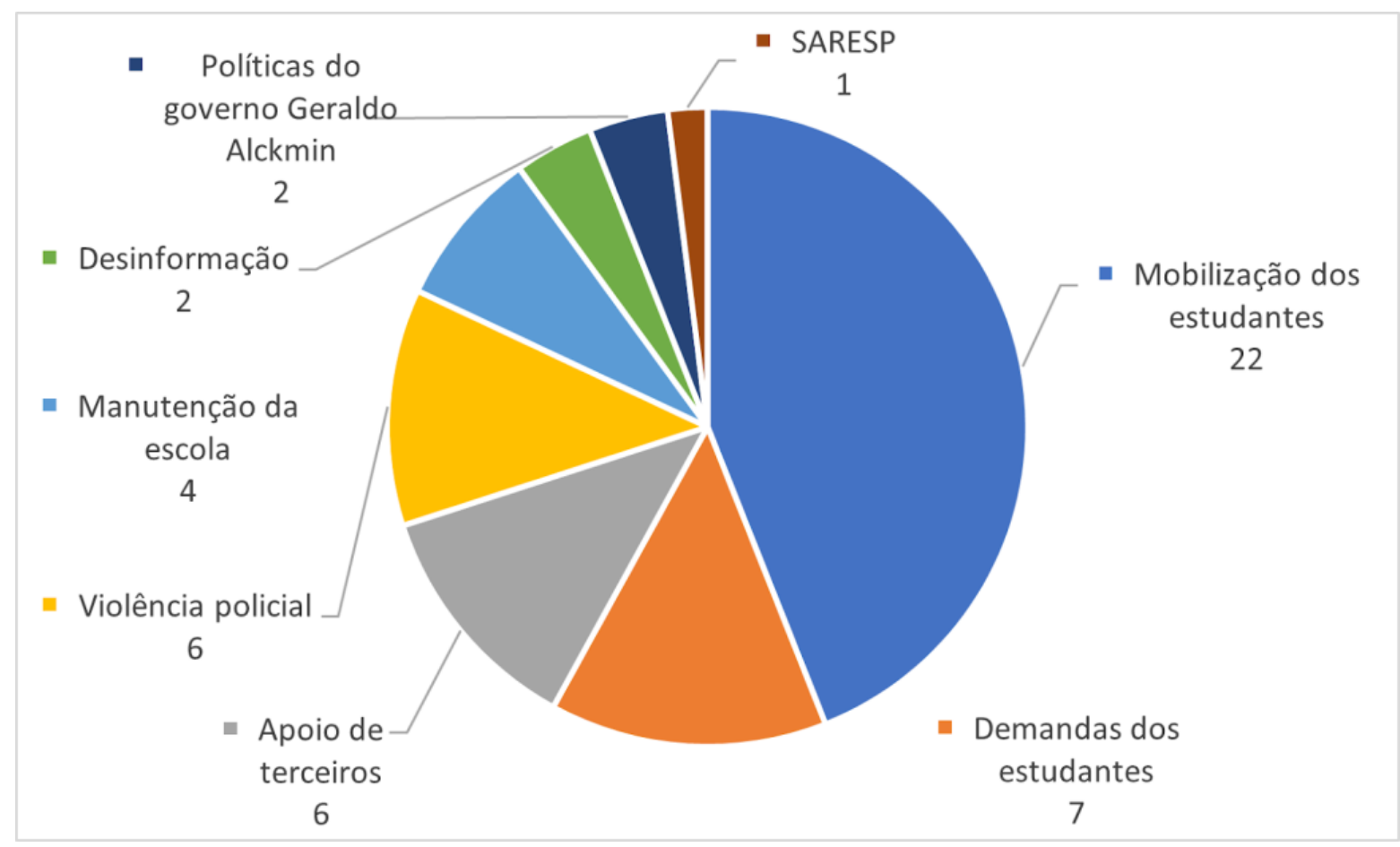

Fonte: Elaboração dos autores.

De acordo com o Gráfico 4, a página "Não Fechem Minha Escola" publicou 15 mensagens sobre mobilizações feitas pelos secundaristas, seja por meio de ocupações de escolas ou manifestações nas ruas, e 13 casos de "Violência policial" contra manifestantes e apoiadores. Em 9 posts analisados identificou-se a manifestação de apoio às ocupações e aos estudantes, seguido de 5 publicações que discutiam políticas adotadas pelo governo de Geraldo Alckmin como reorganizações da pasta da Educação e instruções à Polícia Militar para tratar os secundaristas de maneira truculenta. As demandas dos secundaristas foram elaboradas em duas publicações, assim como a retificação de desinformação contra as ocupações. A categoria "SARESP" é identificada em duas fotos de um gabarito da prova assinalado de forma a montar a palavra "educação". Por fim, a página publicou uma mensagem sobre a popularidade declinante do governo de Geraldo Alckmin e uma mensagem sobre a manutenção das escolas ocupadas. 


\section{Gráfico 4}

Temas abordados pela página "Não Fechem Minha Escola"

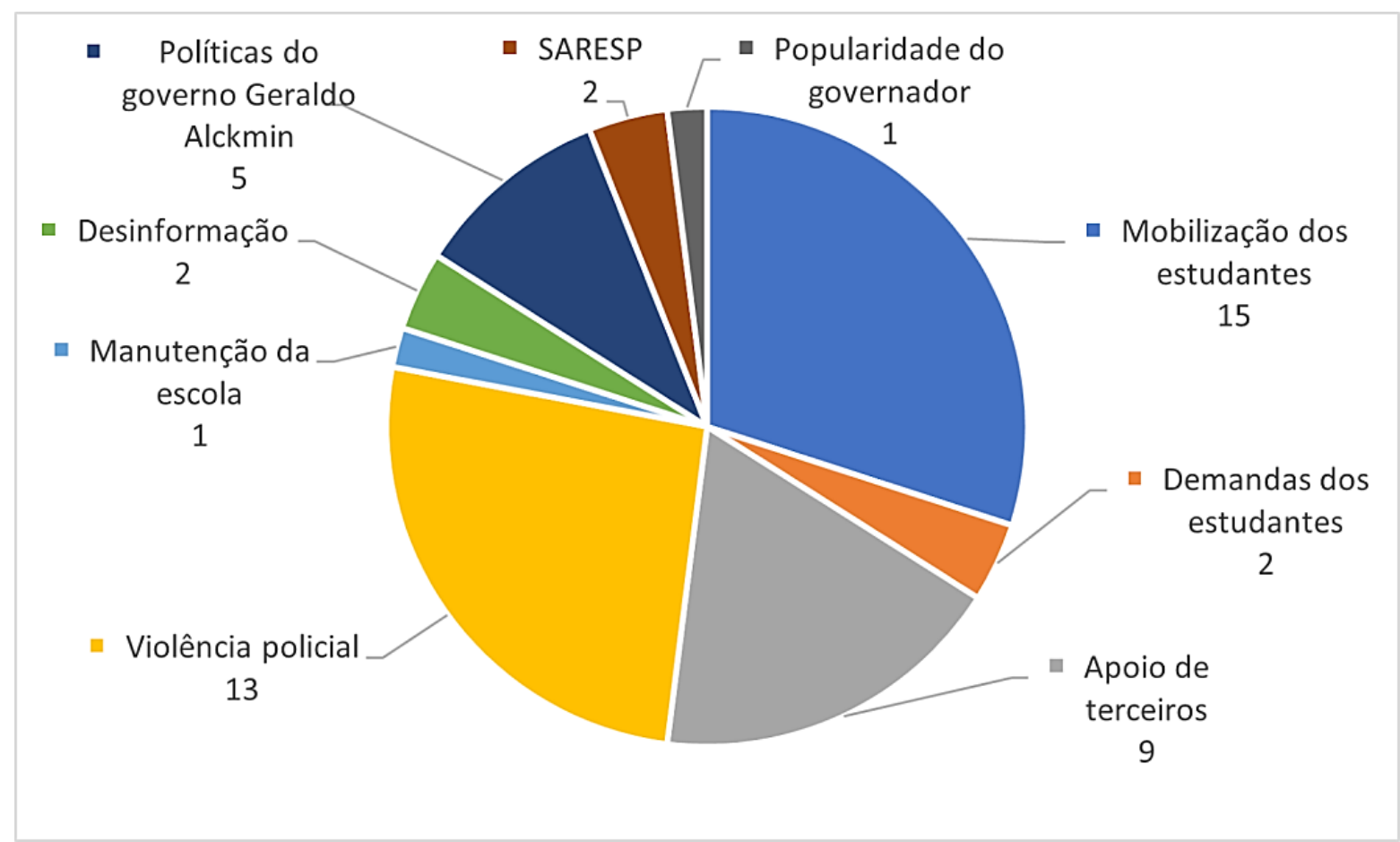

Fonte: Elaboração dos autores.

De acordo com o Gráfico 5, mais da metade das publicações analisadas da página "O Mal Educado" possuíam conteúdo informativo, enquanto 9 delas atacavam o Governador Geraldo Alckmin. As publicações informativas forneciam dados sobre as ocupações, sobre as negociações com o governo do Estado e sobre as manifestações agendadas pelos secundaristas. Os ataques a Geraldo Alckmin focaram a brutalidade policial incentivada pelo governador em áudios de reunião vazados, assim como posicionamentos políticos assumidos por ele. Em seguida, foram identificadas 8 publicações denunciando o tratamento concedido pela Polícia Militar aos estudantes ocupando escolas e 3 posts convocaram seguidores da página a se unir aos secundaristas em protestos. Duas mensagens foram publicadas com enquadramento irônico para se referir a comentários feitos pelo secretário Herman Voorwald e pelo governador Geraldo Alckmin. Por fim, um post apresentou enquadramento de ataque a críticos das ocupações. 


\section{Gráfico 5}

Enquadramento das mensagens da página "O Mal Educado"

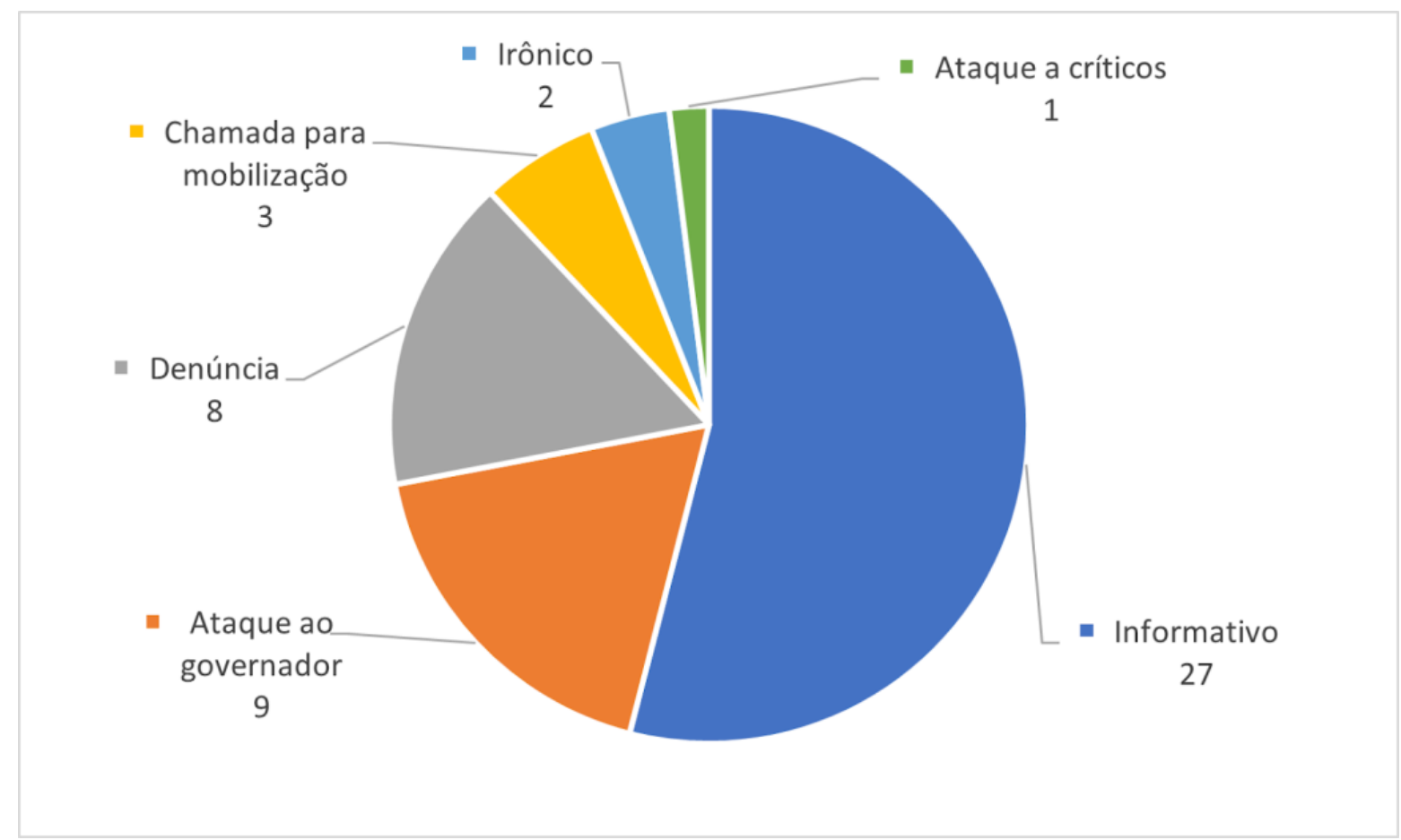

Fonte: Elaboração dos autores.

Do mesmo modo, o Gráfico 6 exibe que a página "Não Fechem Minha Escola" publicou grande quantidade de mensagens com enquadramento informativo, totalizando 20 publicações. É possível notar a grande presença de denúncias em posts do coletivo, chegando a 13 das 50 publicações analisadas. Tanto os ataques ao governador quanto posts irônicos foram identificados em 6 publicações. Em quatro mensagens a página "Não Fechem Minha Escola" buscou mobilizar seus seguidores para se juntarem aos estudantes nas ocupações e nas ruas. Apenas um post foi classificado como "Ataque a críticos" para se referir ao político Fernando Padula. 


\section{Gráfico 6}

Enquadramento das mensagens da página "Não Fechem Minha Escola"

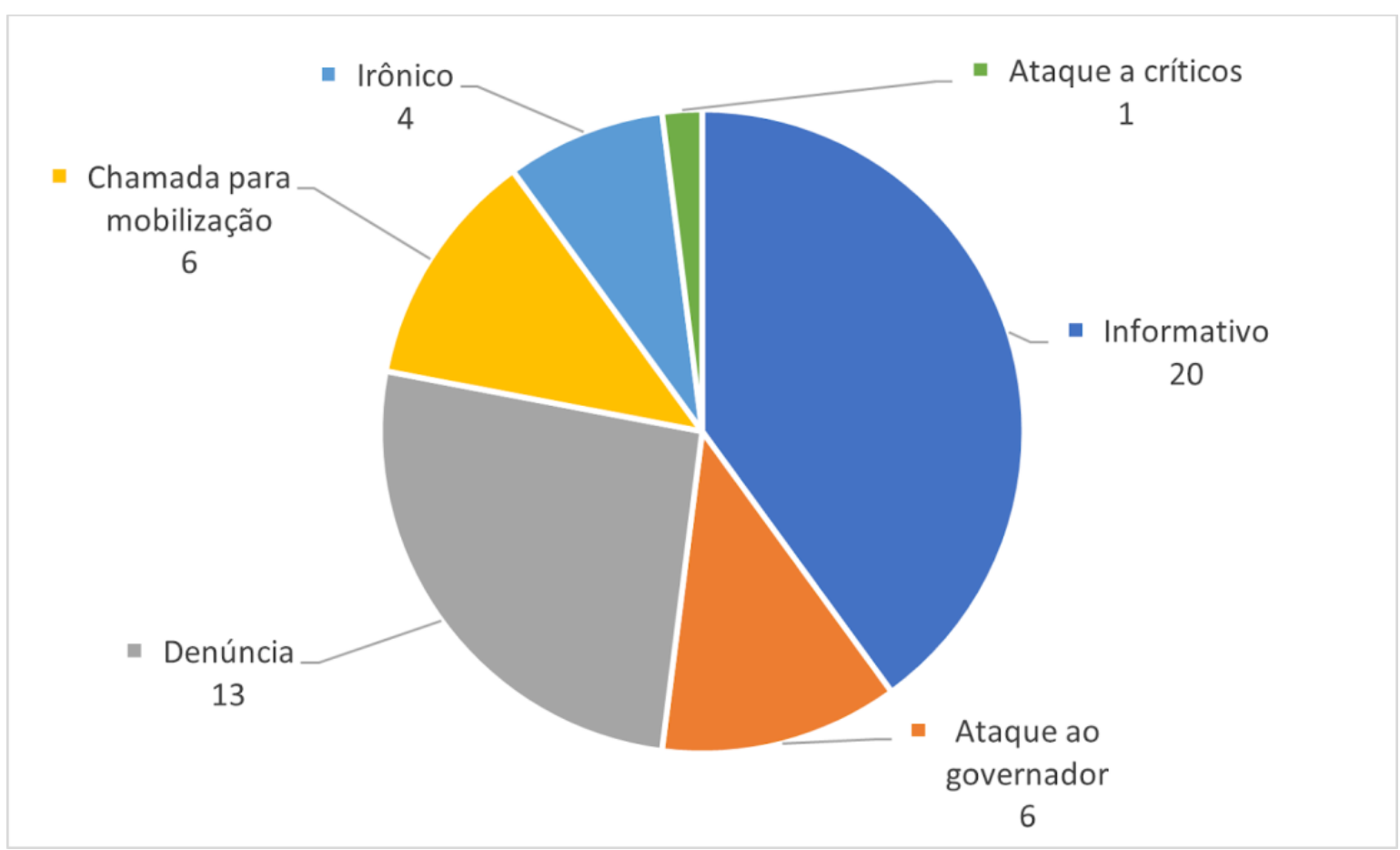

Fonte: Elaboração dos autores.

\section{Análise comparativa: "O Mal Educado" e a "Não Fechem Minha Escola"}

A página do coletivo "O Mal Educado" esteve acompanhando o movimento contra a reorganização das escolas em 2015 desde seu princípio, com a primeira postagem em relação às ocupações tendo sido feita no dia 9 de novembro, às $23 \mathrm{~h} 33 \mathrm{~min}$, sobre a primeira ocupação, da E.E. Diadema. Dois anos antes, o coletivo disponibilizou a cartilha "Como Ocupar um Colégio" em seu blog (e consequentemente em sua página no Facebook), o que serviu como agitador de um movimento que se efetivou e conquistou algumas vitórias em 2015: as escolas estaduais do estado de São Paulo foram ocupadas. Durante o período de ocupações, a página Não Fechem Minha Escola também divulgou manuais (um deles de mobilização e ocupação de escolas, denominado "Não fechem minha escola" e elaborado pela Rede Emancipa de educação popular, e o outro chamado "\#Minas de luta”, um manual tratando de questões relativas ao machismo nas escolas, e como as estudantes poderiam combatê-lo no cotidiano escolar e especificamente nas ocupações). 
Os posts aqui analisados evidenciam o caráter informativo da página do coletivo "O Mal Educado", que acompanhou as ocupações das escolas desde seu início. Em entrevista com integrante do coletivo, fica também evidente a importância do caráter informativo da página: “[...] a galera das ocupações passou a ver a nossa página, e as outras também, Não Fechem Minha Escola, mas sobretudo O Mal Educado, como um veículo oficial” (informação verbal $)^{25}$. Desta forma, as e os estudantes que ocupavam suas escolas enviavam mensagens relativas aos acontecimentos de suas ocupações via mensagem de Facebook e WhatsApp para que as e os administradores da página as publicassem.

Em relação aos temas abordados, foi indicada em entrevista uma perspectiva tática em relação às postagens sobre a manutenção das escolas. Segundo o entrevistado, para o coletivo era mais interessante realizar postagens sobre a postura combativa das e dos estudantes. No entanto, sentiam que abordar esse tema ajudaria a conquistar a opinião pública:

(...) Uma coisa que a gente compartilhava na página que era completamente tático, era (...) que a molecada tava cuidando das escolas. Esse era o post que a gente menos tinha prazer em compartilhar. Pô, a molecada tava fazendo jardinagem na escola, pintando... Isso não é nem obrigação deles, sabe? Só que era um jeito que a gente falava: "meu, vai ganhar opinião pública". Então a gente usava meio taticamente esse tipo de postagem, que tinha bastante alcance e serviram para trazer a opinião pública do nosso lado. Mas não era o que a gente gostava de compartilhar não, a gente gostava de compartilhar as tretas mesmo (informação verbal). ${ }^{26}$

Em relação aos dados coletados, as postagens com esse tema não são maioria em quantidade, no entanto a postagem com maior engajamento (Figura 1) é, de fato, de estudantes da Escola Estadual Pio Telles Peixoto, Zona Oeste da cidade de São Paulo, pintando sua escola durante a ocupação. A postagem é acompanhada de texto, e composta de 5 fotos, resultando em mais de 11.000 reações e de 13.000 compartilhamentos.

\footnotetext{
${ }^{25}$ OME (2020). Entrevista concedida por integrante do coletivo O Mal Educado [ago. 2020]. Entrevistadores: os autores. Google Meets. 1 arquivo .mp4 (102 min).

${ }^{26}$ OME (2020). Entrevista concedida por integrante do coletivo O Mal Educado [ago. 2020]. Entrevistadores: os autores. Google Meets. 1 arquivo .mp4 (102 min).
} 
Figura 1

Postagem de maior engajamento da página "O Mal Educado"

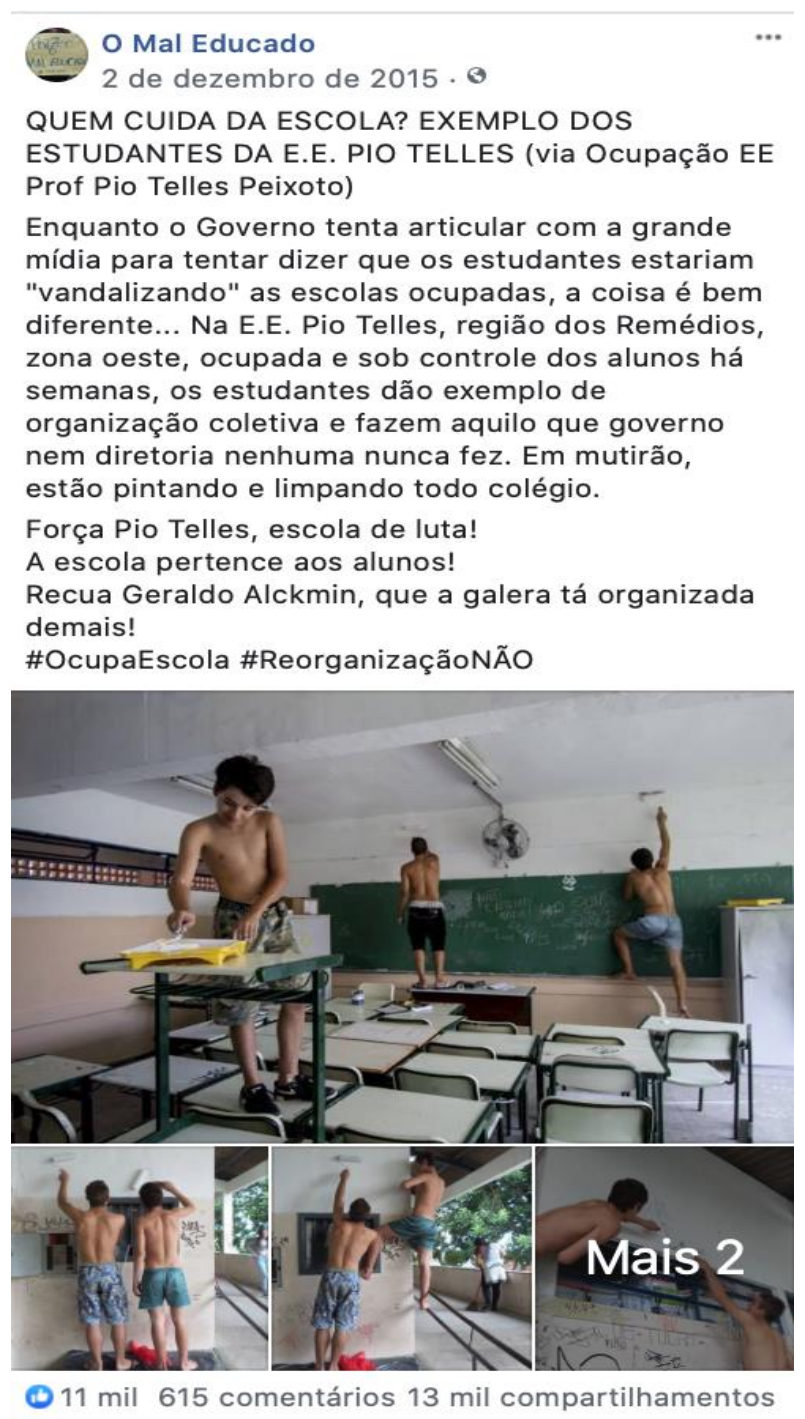

Fonte: Facebook ${ }^{27}, 2015$.

Neste sentido, observando uma média de engajamento por postagem, a estratégia do "O Mal Educado" parece acertada: entre as 50 publicações com maior engajamento são apenas quatro as que têm como tema "Manutenção da escola". No entanto, a média de engajamento é de mais de 10 mil por post, enquanto a segunda temática com maior média (“Apoio de terceiros”) conta com 1.892 de média de engajamento, distribuída por 12 posts, como se pode observar na Tabela 1.

${ }^{27}$ Disponível em https://www.facebook.com/mal.educado.sp/posts/726779044122510/. Acesso em 30 ago. 2020. 


\section{Tabela 1}

Média de engajamento por tema por página

\begin{tabular}{|l|c|c|c|c|c|c|}
\hline \multicolumn{1}{|c}{ Tema } & \multicolumn{3}{c|}{ O Mal Educado } & \multicolumn{3}{c|}{ Não Fechem Minha Escola } \\
\hline & Engajamento & Posts & Média & Engajamento & Posts & Média \\
\hline Manutenção da escola & 40655 & 4 & 10164 & 5390 & 1 & 5390 \\
\hline Apoio de terceiros & 22707 & 12 & 1892 & 112331 & 18 & 6241 \\
\hline Desinformação & 4971 & 6 & 829 & 60708 & 6 & 10118 \\
\hline Demandas dos estudantes & 19519 & 28 & 697 & 11837 & 8 & 1480 \\
\hline Violência policial & 19256 & 30 & 642 & 132063 & 65 & 2032 \\
\hline Mobilização dos estudantes & 51258 & 132 & 388 & 108597 & 90 & 1207 \\
\hline Políticas do governo Geraldo Alckmin & 4357 & 14 & 311 & 30156 & 35 & 862 \\
\hline SARESP & 1675 & 8 & 209 & 9374 & 16 & 586 \\
\hline Popularidade do governador & 0 & 0 & - & 4811 & 9 & 535 \\
\hline
\end{tabular}

Fonte: Elaboração dos autores.

A página "Não Fechem Minha Escola" também adotou uma estratégia informativa, bastante amparada em denúncias de violência policial. A partir da amostra analisada nota-se que os administradores se preocuparam em informar seus seguidores sobre o andamento das ocupações e sobre as ações desenvolvidas pelos secundaristas, ao mesmo tempo que expunham atos violentos cometidos contra os estudantes pela Polícia Militar. Essa estratégia se desenvolveu por meio da publicação de fotos das escolas, dos estudantes, dos protestos e de momentos de agressões capturados por secundaristas e simpatizantes. A página também se utilizou de ilustrações para retratar as escolas ocupadas.

A publicação com maior engajamento da página "Não Fechem Minha Escola" tem caráter semelhante à da "O Mal Educado", uma vez que mostra as e os estudantes limpando a escola (Figura 2), contrapondo reportagem do jornal estadual da Rede Globo, SPTV, na qual imagens de depredação em escola ocupada foram veiculadas. Tal publicação, apesar de evidenciar a manutenção da escola, foi enquadrada no tema "Desinformação", uma vez que utiliza a imagem da manutenção para retificar uma informação do noticiário. 


\section{Figura 2}

Postagem de maior engajamento da página "Não Fechem Minha Escola"

(3) $\mathrm{N}$

Najo fechem minha escola está com Mariza ... Reis

$$
1 \text { de dezembro de } 2015 \text { - } 0
$$

DIGA NĀO A GUERRA SUMA DO ALCKMIN E DA REDE GLOBO!

Na tarde de segunda-feira, os alunos que ocupavam a E.E. Coronel Sampaio foram surpreendidos pela invasalo de pessoas desconhecidas que começaram a destruir toda a escola, colocar fogo em livros didáticos e roubar computadores. A poltcia chegou ao local pouco tempo depois, mas năo impediu a ação daqueles aue depredaram a escola Ameacados, os da lunos nas viram alternativa a no ser delvar olocol os alunos nacviration alo Pouco tempo depoit, chegou a direça da escolo cheie de gabinete da Secretaria de Educaçã. Fernando Padula Novaes.

Hoje, na sessấo da tarde do jornal SPTV da Rede Globo, veio a consagraça da tática: uma reportagem absurdamente mal-carater que induz o telespectador a achar que quem destruilu a escola foram os alunos que a ocupavamt Foram filmados os resultados da depredaça e fol dito que a escola estara ccupad em protesto contra a reorganizaclo, mas em nenhum momento falou-se sobre a invasto das tais pessoas estranhas ao movimento. Em um momento, a repórter chega a flimar uma TV destroçada ao lado de um cobertor, que, segundo a jornalista, -provavelmente cobertor, que, segundo s jornalista, "provaveimente escola". Foram coletadas declaraçóes da diretora da escola, de Fernando Padula Novaes, de um pai "preocupado com o fechamento do ano letivo", Representantes do movimento de ocupaçăo? Nada. Nenhum aluno ocupante foi entrevistado. O maximo de "contraponto" que apareceu foil a fala da dirigente da APEOSP, Maria lzabel Noronha, que, na verdade, nâo disse explicitamente o que ocorreu. Além disso, a APEOSP não é a organizaçăo que dirige as ocupaçōes e nom participa formalmente delas.

Cabe lembrar que esse fato ocorreu logo após reuniăo comvocada pela diretora da E.E. Coronel Sampaio com a comunidade escolar pela desocupaçăo da escola. Mais ainda, ocorteu após a reuniāo ocorrida no domingo em que o mesmo Fernando Novaes orientava dirigentes do ensino a "ir para a guerra" contra os estudantes. Uma guerra suis baseada na violência e manipulaçăo.

Estamos convictos de que os alunas da E.E. Coronel Estamos convictos de que os alunos da E.E. Coronel suas atividades, que sua ocupação apenas melhorava as condiçóes da escola, como ocorre em todas as ocupaçōes. Mais ainda, nJెo vamos sossegar até que os verdadieiros articuladores da destruiça de escolas sejam desmascarados.

Não fechem e não destruam minha escola! Contra a reorganizaçక̧o e a politica rasteira de Geraldo Alckmin!

\#OPOVONäOEEBDOForaRedeGlobo
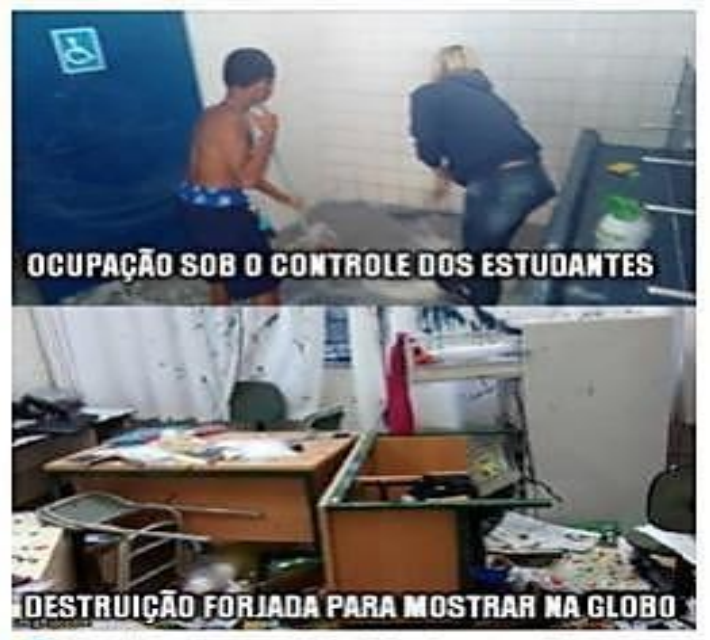

$022 \mathrm{mil} 1 \mathrm{mil}$ comentários 30 mil compartithamentos:

Fonte: Facebook ${ }^{28}, 2015$.

${ }^{28}$ Disponível em https://www.facebook.com/naofechemminhaescola/posts/1496895720605390. Acesso em 30 ago. 2020. 
Enquanto página administrada por ativistas não organizados entre si, com o intuito de reunir informações das diferentes ocupações, os administradores da "Não Fechem Minha Escola" entrevistados indicaram a intenção de dar visibilidade para as ocupações distantes do centro de São Paulo (ABC Paulista, bairros periféricos, etc.): "É óbvio que não tinha como desprezar potência que tinha ocupação da Fernão Dias, mas a gente tentava privilegiar entre muitas aspas, quem não tinha visibilidade nesse processo todo" (informação verbal) ${ }^{29}$.

É interessante observar que em ambas as entrevistas os entrevistados citaram a outra página sem serem especificamente questionados, vendo-a como importante para o movimento das ocupações, mas por vezes enxergando uma diferenciação entre elas. Em relação às escolas, especificamente, na entrevista com os administradores da "Não Fechem Minha Escola", foi destacado que "O Mal Educado reverberava com muito mais força a Fernão Dias do que as demais, porque as pessoas do Mal Educado estavam ocupadas na própria Fernão Dias. Óbvio que em outras escolas também, mas com muita força lá” (informação verbal) ${ }^{30}$. De fato, dentre as 50 postagens com maior engajamento da página "O Mal Educado" analisadas, quatro delas tratam da E.E. Fernão Dias, em Pinheiros, e outras três da E.E. Professor Alves Cruz, na mesma região. Diversas outras escolas, no entanto, aparecem entre tais postagens, incluindo algumas em outros municípios. No caso da página "Não Fechem Minha Escola", as escolas mais citadas nas publicações com maior engajamento são a E.E. Fernão Dias, a E.E. José Lins do Rego e a E.E. Brigadeiro Gavião Peixoto, em São Paulo, e a E.E. Professora Josepha P. Chiavelli, em Jandira. Pode-se observar a distribuição geográfica das escolas citadas nas 50 postagens de cada página nas Figuras 3 e 4.

\footnotetext{
${ }^{29}$ NFME1 (2020). Entrevista concedida por criador e administrador da página Não Fechem Minha Escola [ago. 2020]. Entrevistadores: os autores. Google Meets. 1 arquivo .mp4 (43 min).

${ }^{30} \mathrm{Ibid}$.
} 
Figura 3 - O Mal Educado - Distribuição geográfica das escolas citadas
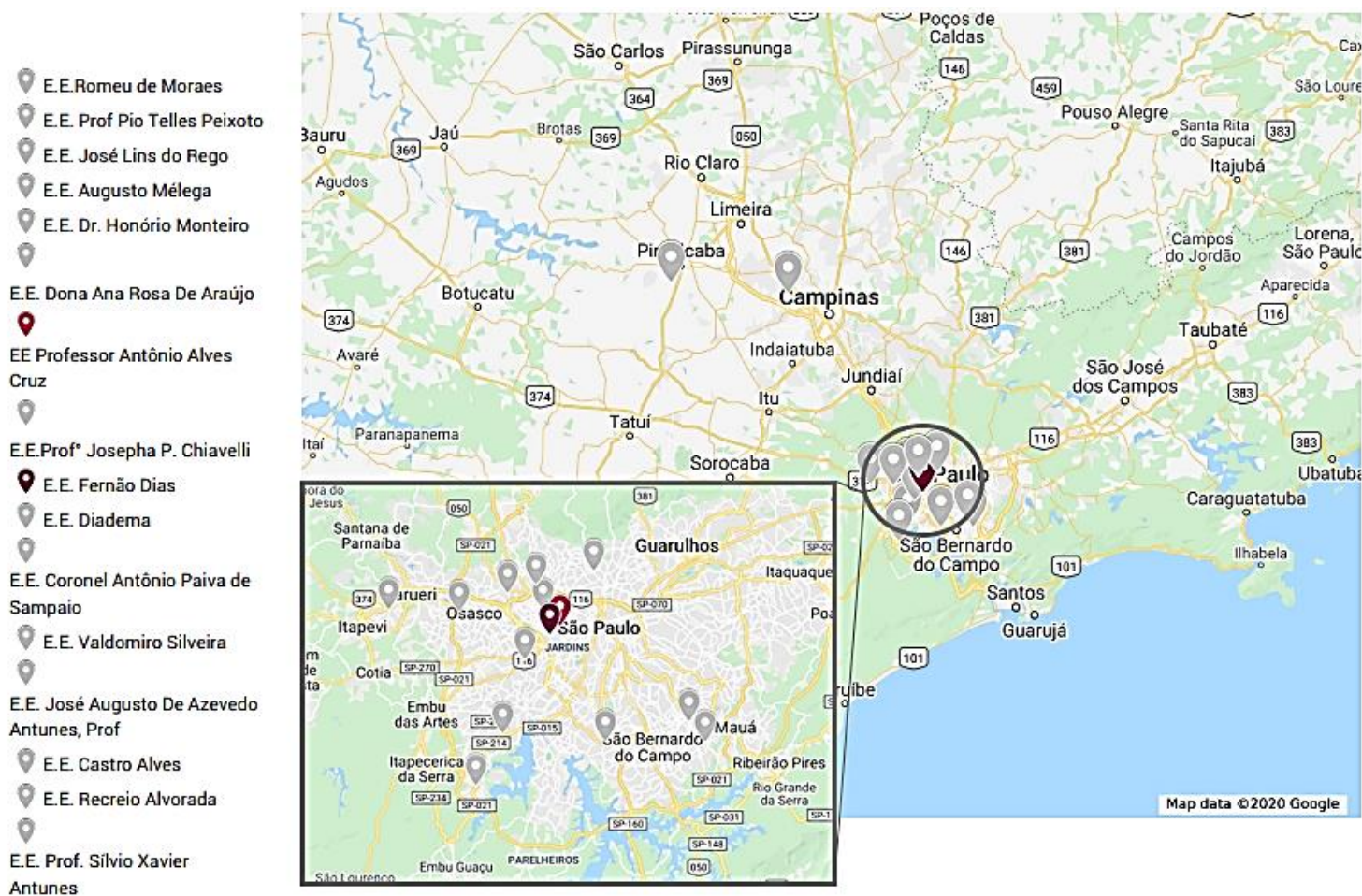

Fonte: Google $\mathrm{Maps}^{31}, 2020$

Figura 4 - Não Fechem Minha Escola - Distribuição geográfica das escolas citadas
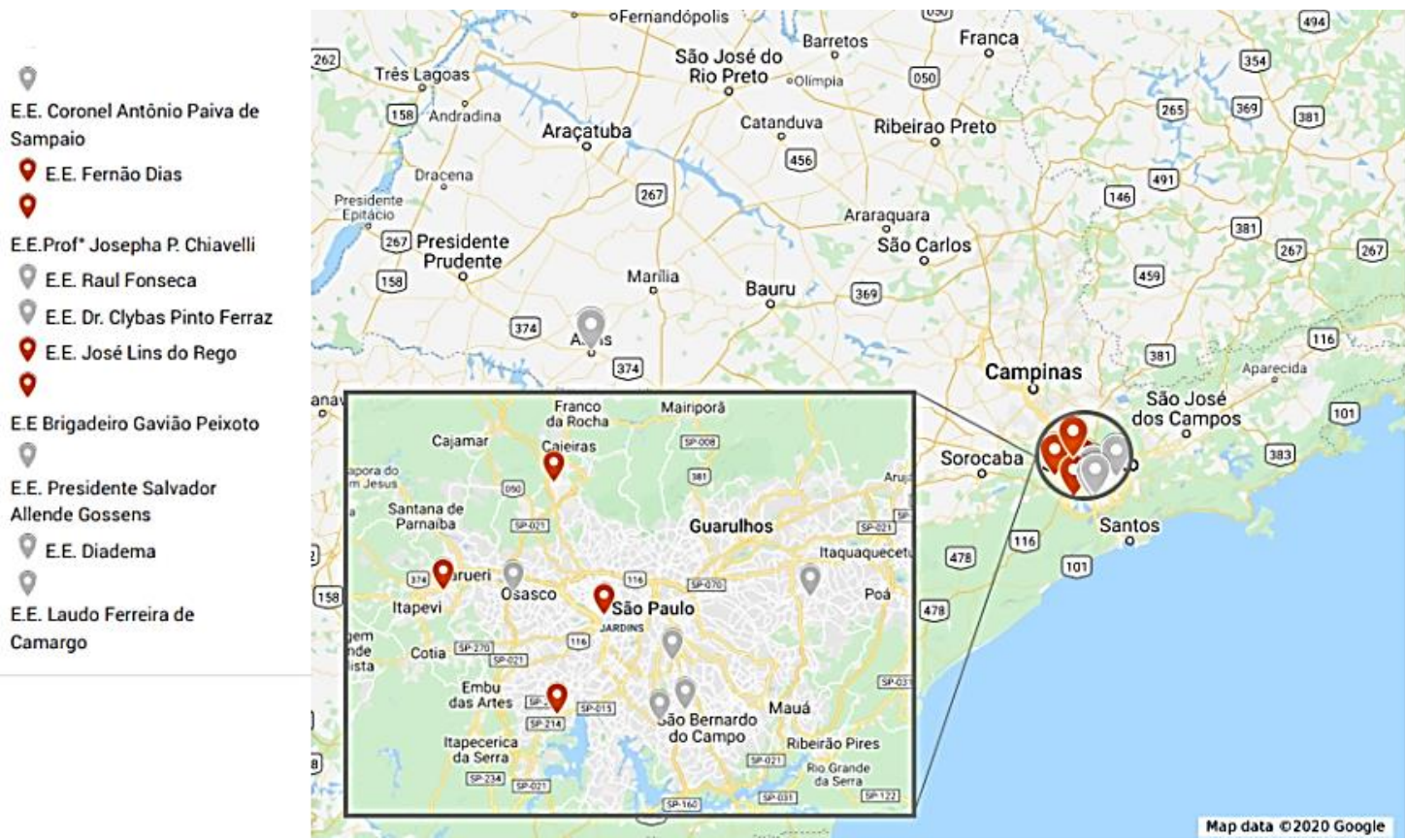

Fonte: Google Maps ${ }^{32}, 2020$.

\footnotetext{
${ }^{31}$ Disponível em

https://www.google.com/maps/d/u/0/viewer?mid=1EzGZiHRRJBPNdSVtZLKnG9GIQp7p2eJf\&ll=$23.197057254069005 \% 2 \mathrm{C}-48.42769649999998 \& \mathrm{z}=8$

${ }^{32}$ Ibid.
} 
As referências dos entrevistados às páginas dos outros, não se limitaram à questão da distribuição geográfica, mas também à atuação nas manifestações. Enquanto coletivo, "O Mal Educado" teve maior atuação no sentido de tomada de decisões, uma vez que comparecia às reuniões do comando de escolas ocupadas. A "Não Fechem Minha Escola" tinha relevância no sentido de que era um forte canal de comunicação, e, portanto, informava muitos dos estudantes. No entanto, como assinalado pelos próprios administradores, não atuavam como coletivo.

Em relação às redes com outros grupos, no caso do coletivo "O Mal Educado" a relação com o Movimento Passe Livre foi levantada por todos os entrevistados, uma vez que grande parte dos integrantes do coletivo eram parte do MPL. Em relação às curtidas da página "O Mal Educado", esta curte, no geral, páginas de escolas e ocupações de escolas, bem como de alguns meios de comunicação alternativos, de artistas, outros coletivos (no geral, de vertente anarquista), e uma página de Juventude Partidária (JPT Araraquara ${ }^{33}$ ).

As relações da página "Não Fechem Minha Escola" são menos diretas. Para o entrevistado do coletivo "O Mal Educado", esta página tinha vínculos diretos com os coletivos Juntos e o Partido Socialismo e Liberdade (PSOL), sendo que este pontuou que lideranças do partido não acreditavam que a ocupação de escolas fosse uma alternativa real, entendendo que era apenas uma palavra de ordem para pressionar o governo durante as manifestações (informação verbal) ${ }^{34}$. Um dos entrevistados da "Não Fechem Minha Escola", que na época era estudante secundarista, pontuou que, no geral, as e os estudantes não relacionavam diretamente a página a um partido ou coletivo, mas que havia sempre uma dúvida de quem estava por trás desta página (informação verbal) ${ }^{35}$. $\mathrm{O}$ administrador e criador da página "Não Fechem Minha Escola" pontuou algumas vezes que havia proximidade da página com a Rede Emancipa (uma rede de cursinhos populares), uma vez que esta já atuava em algumas das escolas ocupadas, e com o coletivo Juntos, do qual ele próprio fazia parte, sem, no entanto, ser uma página vinculada a alguma das organizações (informação verbal) ${ }^{36}$. As curtidas da página "Não Fechem Minha Escola" são também, em sua maioria, para páginas de escolas e ocupações de escolas, mas contam ainda com meios de comunicação

\footnotetext{
${ }^{33}$ Disponível em https://www.facebook.com/jptararaquara/

${ }^{34}$ OME (2020). Entrevista concedida por integrante do coletivo O Mal Educado [ago. 2020]. Entrevistadores: os autores. Google Meets. 1 arquivo .mp4 (102 min).

35 NFME2 (2020). Entrevista concedida por administrador da página Não Fechem Minha Escola [ago. 2020]. Entrevistadores: os autores. Google Meets. 1 arquivo .mp4 (43 min).

${ }^{36}$ NFME1 (2020). Entrevista concedida por criador e administrador da página Não Fechem Minha Escola [ago. 2020]. Entrevistadores: os autores. Google Meets. 1 arquivo .mp4 (43 min).
} 
alternativos, coletivos, artistas e personalidades (como a página da chef Paola Carosella ${ }^{37}$, cuja demonstração de apoio às ocupações rendeu uma das publicações com maior engajamento da página), páginas voltadas para divulgação científica, páginas vinculadas ao coletivo Juntos e à Rede Emancipa, e por fim páginas de mandatos coletivos e candidatas ou personalidades políticas já eleitas, todas do Partido Socialismo e Liberdade (PSOL).

\section{Conclusões}

Maria da Glória Gohn (2017) observa o movimento de ocupações secundaristas como um ciclo de luta estudantil que durou até pelo menos 2016 com as ocupações das escolas técnicas no Estado de São Paulo e também em diferentes estados como Rio de Janeiro, Paraná e Rio Grande do Sul, colocando-os inclusive como "novíssimos movimentos sociais" por conta de suas características, entre as quais o uso das redes, que fora fundamental. Além disso, o movimento de 2015 se mostrou vitorioso com a suspensão do projeto de reestruturação e com uma inédita rejeição da população de São Paulo em relação ao Governo Estadual, talvez por isso foram de grande influência as ocupações por todo o Brasil nos anos seguintes. Grande parte dessa importância tem relação com o uso das redes para divulgação de suas próprias informações em oposição à mídia tradicional que em grande medida ignorava os protestos ou os representava de uma forma negativa. É importante ressaltar que com o tempo foi ocorrendo o fechamento de salas de forma mais velada, além de muitas declarações de estudantes que participaram da luta que foram expulsos de suas antigas escolas e perseguidos por forças policiais.

A relevância dos coletivos no período das ocupações fica evidente na figura do "O Mal Educado", que divulga o manual "Como Ocupar um Colégio", iniciando esta forma de atuação pelos estudantes secundaristas insatisfeitos com a proposta de reorganização escolar, e que atua durante as ocupações em reuniões e trazendo um espaço autônomo para informar as estudantes e a população em geral sobre as ocupações. Outras páginas cumpriram também este papel, como as específicas das ocupações de cada escola e a "Não Fechem Minha Escola", aqui também analisada. Além disso, ao retomarmos as principais características dos coletivos analisados no trabalho em questão (Gohn, 2017; Augusto; Rosa; Resende, 2016; Maia, 2013; Neto, 2018; Peralva et al., 2017; Perez; Souza, 2017) é possível afirmar que a própria dinâmica de todos os processos das manifestações secundaristas em 2015, desde os primeiros protestos até as ocupações em si, foi muito baseada na ação direta, horizontalidade,

${ }^{37}$ Disponível em https://www.facebook.com/paolacarosellaoficial/ 
organização em comissões, críticas a modelos menos participativos e hierarquizados de política, além do uso constante de tecnologias de informação e comunicação e o fato de serem jovens (Gohn, 2017; Augusto; Rosa; Resende, 2016). Todas essas características estão presentes nos mais diversos coletivos analisados pelos autores em questão.

A partir dos dados analisados, pôde-se observar que as publicações das páginas alternam entre conteúdo esperançoso e conteúdo combativo, destacando as ocupações bemsucedidas e denunciando violações de direitos e casos de desinformação transmitidos pelo então Governador e mídias de notícias. No entanto, os posts da página "Não Fechem Minha Escola" obtiveram engajamento superior àqueles da página "O Mal Educado".

Ambas as páginas utilizaram diversos recursos audiovisuais e mantiveram uma consistência entre os temas abordados. A página "O Mal Educado" priorizou mensagens com conteúdo voltado para ações dos secundaristas dentro e fora das escolas, uma estratégia defendida pelos ativistas desse coletivo com o objetivo de influenciar positivamente a opinião pública em relação aos estudantes. Por outro lado, a página "Não Fechem Minha Escola" deu grande enfoque às denúncias contra atos de violência policial e, segundo os administradores da página, priorizaram publicações sobre escolas no Grande $\mathrm{ABC}$ e em regiões periféricas a fim de apresentar a amplitude das ocupações pelo estado de São Paulo.

O enquadramento das mensagens apresenta certa distinção e evidencia as diferentes estratégias de comunicação das páginas. As publicações da página "O Mal Educado" apresentam o uso de memes e ironia para discutir assuntos relacionados às ocupações e para atacar o então Governador Geraldo Alckmin, enquanto a página "Não Fechem Minha Escola" publicou mensagens com tom de denúncia, especialmente para noticiar casos de abordagens violentas, abusos de autoridade e confrontos entre secundaristas, manifestantes e a Polícia Militar. Segundo os ativistas ligados ao coletivo "O Mal Educado", ao longo das ocupações a página se tornou uma central de informações sobre o status das escolas e das manifestações programadas e, desse modo, as publicações da página possuem forte caráter informativo.

De forma geral, percebe-se que tais páginas foram importantes para aglutinar informações vindas das diferentes ocupações e serviram, assim como com as páginas específicas de cada ocupação e as mídias alternativas (Jornalistas Livres, principalmente), para contrapor ataques vindos do próprio governo e também da mídia tradicional. Além disso, houve atuação estratégica, como indicado pelo membro do coletivo "O Mal Educado", no sentido de evidenciar as ações das e dos estudantes no cuidado com as escolas, buscando maior apoio da opinião pública. Nesse sentido, a publicação de fotos de secundaristas limpando e realizando a manutenção das instalações das escolas, assim como a divulgação de 
apoio por parte de personalidades da mídia brasileira, colaboraram em certo grau com a legitimação das ocupações e das demandas dos e das estudantes. Assim, fica evidente o uso das novas tecnologias, com foco especial aos aparelhos móveis, como parte fundamental da luta dos secundaristas em 2015.

\section{Referências}

ALONSO, Angela (2017), “A Política Das Ruas: Protestos em São Paulo de Dilma a Temer”. Novos Estudos. CEBRAP. São Paulo, ed. especial, jun., pp. 49-58 [Consult. 03-10-2020]. Disponível em http://novosestudos.uol.com.br/wp-content/uploads/2018/07/Angela-Alonso_A-pol\%C3\%ADticadas-ruas.pdf

ANJOS REBELDES (2015), Caminhos da Reportagem. Reportagem: Eduardo Goulart de Andrade. Produção: Aline Beckstein; Eduardo Goulart de Andrade; Luana Ibelli; Thaís Rosa. Roteiro e Direção: Bianca Vasconcellos (51 min). Brasília, TV Brasil [Consult. 06-10-2020]. Disponível em https://www.youtube.com/watch?v=necSPQchYXk\&feature=emb_title

AUGUSTO, Acácio; ROSA, Pablo O.; RESENDE, Paulo Edgar da R. (2016), "Capturas e resistências nas democracias liberais: uma mirada sobre a participação dos jovens nos novíssimos movimentos sociais". Revista Estudos de Sociologia. Araraquara, v. 21, n. 40, pp. 21-37, jan.-jun. [Consult. 0610-2020]. Disponível em https://periodicos.fclar.unesp.br/estudos/article/view/7581

BACHINI, Natasha; AVANZI, Clarice; PENTEADO, Claudio L. de C.; MARTINHO, Silvana. (2015), "Curtiu? O uso do Facebook nas eleições municipais de São Paulo em 2012”, In: A. Aldé; F. P. J Marques (Orgs.), Internet e Poder Local. 1ed. Salvador, UFBA, pp. 141-176.

BENNETT, W. Lance; SEGERBERG, Alexandra (2012), "The logic of connective action: Digital media and the personalization of contentious politics", Information, Communication \& Society, v. 15 , n. 5, pp. 739-768.

CAMPOS, Antonia (2019). "Escolas de luta, ladrões de merenda: dois momentos das ocupações secundaristas de São Paulo", in J. Medeiros; A. Januário; R. Melo (Orgs.), Ocupar e Resistir. Movimentos de ocupação de escolas pelo Brasil (2015-2016). $1^{\text {a }}$ ed. São Paulo, Editora 34, pp. 79102.

CAMPOS, Antonia; MEDEIROS, Jonas; RIBEIRO, Márcio (2016), Escolas de Luta. Ed. Veneta, Coleção Baderna, São Paulo.

CASTELLS, Manuel (2013), Redes de Indignação e Esperança. Ed. Zahar, Rio de Janeiro.

DAY, Richard J. F. (2005), Gramsci is Dead: Anarchist currents in the newest social movements. Pluto Press, London.

DI FELICE, Massimo (2017). Net-ativismo: Da ação social para o ato conectivo. Paulus Editora, São Paulo.

GERBAUDO, Paolo (2014), "The persistence of collectivity in digital protest", Information, Communication \& Society, v. 17, n. 2, pp. 264-268.

GOHN, Maria G. (2017), Manifestações e Protestos no Brasil: correntes e contracorrentes na atualidade. Cortez Editora, São Paulo. 
JANUÁRIO, Adriano; CAMPOS, Antonia M.; MEDEIROS, Jonas; RIBEIRO, Márcio M. (2016), “As Ocupações das Escolas em São Paulo (2015): autoritarismo burocrático, participação democrática e novas formas de luta social". Revista Fevereiro, São Paulo, v. 9, pp. 1-26 [Consult. 06-10-2020]. Disponível em https://www.revistafevereiro.com/pag.php?r=09\&t=12

MAIA, Gretha L. (2013), "A juventude e os coletivos: como se articulam novas formas de expressão política". Revista Eletrônica do Curso de Direito UFSM. Universidade Federal de Santa Maria, Santa Maria, v. 8, n. 1, pp. 58-73 [Consult. 06-10-2020]. Disponível em https://periodicos.ufsm.br/revistadireito/article/view/8630/pdf

NETO, Fernando L. (2018), "Os sentidos de participação na formação de coletivos". In: Anais $42^{\circ}$ Encontro Anual da ANPOCS. GT 24: Pluralismo, identidade e controvérsias sociopolíticas. Caxambu, out. Disponível em http://www.anpocs.com/index.php/encontros/papers/42-encontroanual-da-anpocs/gt-31/gt24-19/11318-os-sentidos-de-participacao-na-formacao-de-coletivos/file [Consult. 06-10-2020].

ORTELlADO, Pablo (2016), "Prefácio - A primeira flor de julho", in A. M. Campos; J. Medeiros; M. M. Ribeiro (orgs.). Escolas de Luta. Ed. Veneta, Coleção Baderna, São Paulo.

PENTEADO, Claudio L. C.; SANTOS, Marcelo B. P.; ARAÚJO, Rafael de P. A. (2009), "Metodologia de pesquisa de blogs de política: análise das eleições presidenciais de 2006 e do movimento 'cansei'". Revista de Sociologia e Política, Curitiba, v. 17, pp. 159-181 [Consult. 0610-2020]. Disponível em https://revistas.ufpr.br/rsp/article/view/29356/19119

PERALVA, Angelina; FIGEAC, Julien; PATON, Nathalie; NOGUEIRA, Rachel (2017), "O legado de 2013. Coletivos de ativistas e a Agenda Pública Brasileira", in Anais do $41^{\circ}$ Encontro Anual da ANPOCS, GT 8: Democracia e Desigualdade. Caxambu [Consult. 06-10-2020]. Disponível em https://www.anpocs.com/index.php/papers-40-encontro-2/gt-30/gt08-26/10660-o-legado-de-2013coletivos-de-ativistas-e-a-agenda-politica-brasileira/file

PEREZ, Olivia C.; SOUZA, Bruno M. (2017), "Velhos, Novos ou Novíssimos Movimentos Sociais? As pautas e práticas dos coletivos", in Anais do $41^{\circ}$ Encontro Anual da ANPOCS, GT 11: Entre Ruas $e$ os Gabinetes. Caxambu [Consult. 06-10-2020]. Disponível em http://anpocs.com/index.php/encontros/papers/41-encontro-anual-da-anpocs/gt-30/gt11-15/10696velhos-novos-ou-novissimos-movimentos-sociais-as-pautas-e-praticas-dos-coletivos/file

PINHEIRO-MACHADO, Rosana (2019), Amanhã Vai Ser Maior. O que aconteceu com o Brasil e possiveis rotas de fuga para a crise atual. Ed. Planeta, São Paulo.

ROMANCINI, Richard; CASTILHO, Fernanda (2017), "Como Ocupar Uma Escola? Pesquiso na Internet!": Política participativa nas ocupações de escolas públicas no Brasil” Intercom - RBCC, São Paulo, v. 40, n. 2, pp. 93-110 [Consult. 06-10-2020]. Disponível em https://www.scielo.br/pdf/interc/v40n2/1809-5844-interc-40-2-0093.pdf

ZIBAS, Dagmar M. (2008), “'A Revolta dos Pinguins” e o Novo Pacto Educacional Chileno". Revista Brasileira de Educação. Fundação Carlos Chagas, São Paulo, v. 13, n. 38 [Consult. 06-10-2020]. Disponível em https://www.scielo.br/pdf/rbedu/v13n38/02.pdf 


\begin{abstract}
This paper describes the use of social networks, an essential tool for publicizing information and organizing students, during the occupancy period of high schools in 2015 through a comparative study of the two most relevant Facebook pages during the events: "O Mal Educado" e "Não Fechem Minha Escola". The first page was managed by a namesake collective, and the last one was created by nonorganized activists. The methodology applied is based on interviews with page administrators and content analysis of the 50 most engaged posts of each page. The pages are different in many aspects as the communication strategy, the management board composition, and the networks from their come. The analyzed posts have similar subjects but different frames and media.
\end{abstract}

Keywords: Collectives; high school occupancies; network mobilization; Facebook.

\title{
Resumen
}

Este artículo trata del uso de las redes sociales, muy importantes para difundir información y organizar a los estudiantes, durante el período de las ocupaciones de las escuelas en 2015. A partir del estudio comparativo de las dos páginas de Facebook más activas durante los eventos: "O Mal Educado" y "Não Fechem Minha Escola". La primera gerenciada por el colectivo de mismo nombre y la segunda creada por activistas no organizados. La metodología utilizada ha incluido entrevistas con los administradores y análisis de contenido de 50 publicaciones con más engagement de cada página. Las páginas difieren en relación a la visión sobre la estrategia de comunicación, la composición de la gerencia y las redes de las cuales pertenecieron en el movimiento. Las publicaciones analizadas se asemejan en relación a los temas abordados, pero presentan algunas diferencias cuanto a los encuadramientos y recursos utilizados.

Palabras clave: Colectivos; ocupaciones de secundaria; movilizaciones en red; Facebook. 